\title{
Isolation and Identification of Lactobacillus brevis from Local Cheese of Bazoft and Evaluation of Antimicrobial Activity Against Some Pathogenic Microorganisms
}

\author{
Iman Dehghani Champiri ${ }^{1}$, Zahra Bamzadeh*1,2 (D), Ebrahim Rahimi ${ }^{3}$, Leila Rouhi ${ }^{4}$
}

1. Department of Microbiology, Faculty of Basic Sciences, Shahrekord Branch, Islamic Azad University, Shahrekord, Iran

2. Department of Microbiology, Shahr-e-Qods Branch, Islamic Azad University, Tehran, Iran

3. Department of Food Hygiene and Public Health, Faculty of Veterinary Medicine, Shahrekord Branch, Islamic Azad University, Shahrekord, Iran

4. Cellular and Developmental Research Center, Faculty of Basic Sciences, Shahrekord Branch, Islamic Azad University, Shahrekord, Iran

\section{ABSTRACT}

Background and Aim: Many local dairy products in Iran contain lactic acid bacteria. The aim of this study was to isolate and identify Lactobacillus brevis from the cottage cheese made in Bazoft city using biochemical and molecular methods and investigate its antimicrobial properties in vitro.

Materials and Methods: In this study, ten local Bazoft city cheese samples were collected. After transferring to the Lab, serial dilution was obtained at $10^{-6} \mathrm{CFU} / \mathrm{mL}$ and cultured in MRS medium. Then bacilli and gram-positive bacteria were isolated and identified by biochemical methods. The identified Lactobacillus brevis genome was extracted and then amplified using polymerase chain reaction (PCR) to confirm the isolated strain. Finally, the PCR product was sent to Sinaclon for sequencing. The antimicrobial properties of Lactobacillus brevis supernatant were evaluated using the disk and well diffusion method against Escherichia coli, Staphylococcus aureus, Salmonella typhimurium, Pseudomonas aeruginosa, and Enterococcus faecalis. Antibiotic susceptibility was also assessed by the CLSI standard method.

Results: Six species of Lactobacillus were identified from cottage cheese samples. Selected L. brevis showed good antimicrobial potency against five pathogenic bacteria. It showed the highest inhibitory effect against $S$. typhimurium during the well diffusion method with a mean diameter of growth inhibition zone of $19 \mathrm{~mm}$ and the least inhibitory effect against E. faecalis during the disc method with a growth inhibition zone diameter of $9 \mathrm{~mm}$. It was also resistant to the antibiotics Vancomycin and Gentamicin, intermediate susceptible to Kanamycin and Nalidixic acid, and susceptible to Erythromycin, Tetracycline, Ampicillin, and Chloramphenicol.

Conclusion: Isolated L. brevis strain from the local Bazoft cheese has a good antimicrobial ability. By performing extra in vitro and in vivo tests, this native strain can be used more in medicines and the food industry.

Keywords: Lactobacillus brevis, Pathogenic bacteria, Antibiotic resistance, Local cheese

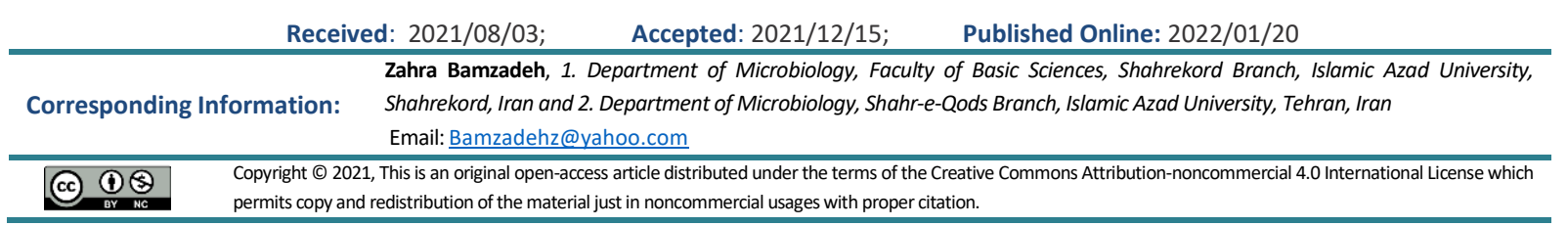

Use your device to scan and read the article online

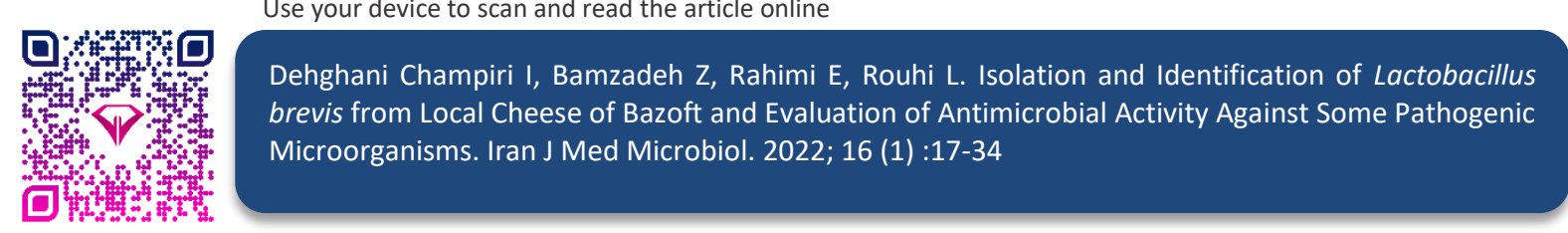

Download citation: $\underline{B i b T e X}$ | RIS | EndNote | Medlars | ProCite | Reference Manager | RefWorks | Send citation to: $\otimes_{\text {Mendeley }} \boldsymbol{Z}_{\text {zotero }} \mathbb{H}_{\text {RefWorks }}$

\section{Introduction}

Fermented dairy products are a good source for isolating microorganisms $(1,2)$. Cottage cheeses made from raw milk have a high genetic diversity and a more complex microbial ecosystem than other dairy products (3). Cheese traditionally produced from raw milk has a variety of genus, species, and native 
microbial flora of the milk used in the preparation process (4). Cheese is produced due to the coagulation of casein by the renin enzyme or similar enzymes in the presence of lactic acid produced by microorganisms (5). Lactic acid bacteria that become part of the predominant microbial flora during the cottage cheese ripening (after one month) are often from the facultatively heterofermentative Lactobacilli (FHL) (6). Lactic acid bacteria are dietary supplements known for their fermentability and health and nutritional benefits. For this reason, they have beneficial effects on the host and help balance the microbial flora of the intestine, such as Lactobacillus (7).

Lactobacilli are a type of lactic acid bacteria considered safe bacteria. These bacteria are grampositive, non-spores, catalase-negative, and are usually immobile (8). Lactobacilli have potent antagonistic activity against many microorganisms, including food spoilage organisms and pathogens. The production of secondary metabolites, lactic acid, and the resulting decrease in $\mathrm{pH}$ are the main factors in food preservation. In addition, some strains can help preserve fermented foods producing other inhibitors, such as bacteriocins (9). Lactobacilli produce various compounds such as Hydrogen peroxide and organic acids during lactic fermentation that can have inhibitory effects on many microorganisms (10). Due to increasing antibiotic resistance and side effects of chemical drugs, using alternative therapies is essential (11). These bacteria and their metabolites can be used therapeutically (12). Studies confirm the positive role of lactic acid bacteria in inhibiting pathogens $(13,14)$.

Due to its long-term use in various food products that are traditionally fermented, Lactobacillus brevis, as an essential member of the genus Lactobacillus, has a GRAS (generally recognized as safe) status that is isolated from milk, cheese, mouth, and gastrointestinal tract (15). The aim of this study was to isolate L. brevis from cottage cheese of Bazoft, Chaharmahal and Bakhtiari Province, Iran, and investigate its antibiotic resistance and antimicrobial ability of supernatant (culture supernatant) on pathogenic bacterial strains.

\section{Materials and Methods}

\section{Sampling}

In this study, 10 samples of cottage cheese were randomly collected from rural areas of Bazoft, Chaharmahal and Bakhtiari Province, Iran. The samples were transferred to the microbiology laboratory of Islamic Azad University Shahrekord Branch under cold conditions and kept at $4^{\circ} \mathrm{C}$ until the beginning of the experiment.

\section{Sample Preparation and Initial Culture}

Serial dilution of samples in sterile physiological solution was obtained at $10^{-6}$ (16). Then, for initial isolation, $1 \mathrm{ml}$ of each cottage cheese sample was added to $9 \mathrm{~mL}$ of MRS broth (Merck, Germany) (de MAN, ROGOSA, and SHARPE). The samples were placed in an anaerobic jar for $24-48$ hours at $37^{\circ} \mathrm{C}$. Then, to obtain a single colony from the samples, the streak plate method was performed using a sterile inoculation needle on MRS agar and incubated for 3748 hours at $37^{\circ} \mathrm{C}(17)$.

\section{Morphological Study}

First, Gram's method was performed for each colony, and then they were examined and recorded using an optical microscope at 100x magnification (18).

\section{Biochemical Properties Investigation}

Oxidase, catalase, motion, indole, endospore, and $\mathrm{H} 2 \mathrm{~S}$ tests were used to identify Lactobacillus. Also, the ability to grow at 15 and $45^{\circ} \mathrm{C}$ after 48 hours was evaluated $(19,20)$.

\section{Carbohydrate's Fermentation}

A Carbohydrate-free MRS medium was used for this purpose. Nine $\mathrm{mL}$ of MRS broth medium containing one percent of the desired carbohydrates (Arabinose, cellobiose, Melezitose, Melibiose, Raffinose, Ribose, and Sucrose) and phenol-red reagent were added to each test tube. Then one $\mathrm{mL}$ of the desired bacteria $\left(10^{7}\right.$ $\mathrm{CFU} / \mathrm{mL}$ ) was inoculated into each tube and incubated for 48 hours at $37^{\circ} \mathrm{C}$. Turning the red color of the environment to yellow means consuming the desired sugar. The results of carbohydrate fermentation were compared with the standard table of Bergey's Manual of Systematic Bacteriology after the experiment (21).

\section{Molecular Identification and Sequencing}

Polymerase chain reaction (PCR) was used to identify and confirm the bacteria by molecular method. For this purpose, DNA was first extracted from the bacterial sample according to the protocol of the DNA extraction kit (Sinaclon, Iran). The extracted sample was used as a template for the PCR reaction. Sequence (5'-CTCAAAACTAAACAAAGTTTC- 3 ') as forward primer and sequence (5'-CTTGTACACACC GCCCGTCA-3') as reverse primer were used (22). PCR reaction in $25 \mu \mathrm{L}$ volume including $12.5 \mu \mathrm{L}$ PCR buffer with 10 times density, $25 \mu \mathrm{M}$ forward and reversed primer $0.5 \mu \mathrm{L}$ each, $1 \mu \mathrm{L}$ of $50 \mathrm{mM}$ Magnesium chloride, $4 \mu \mathrm{L}$ of $1.25 \mathrm{mM}$ of dNTPs, 2.5 units of Taq DNA Polymerase enzyme, and $4 \mu \mathrm{L}$ of extracted DNA, was performed. Reaction in a thermal cycler (FlexCycler2, Germany) with temperature conditions of 5 minutes, denaturation at $95^{\circ} \mathrm{C}$ and then 30 cycles including denaturation at $95^{\circ} \mathrm{C}$ for 1 minute, annealing at $55^{\circ} \mathrm{C}$ for 1 minute, extension at $72^{\circ} \mathrm{C}$ for 1 minute and final extension at $72^{\circ} \mathrm{C}$ for 10 minutes was performed. The product was electrophoresed in $1 \%$ agarose gel and then examined on gel doc (AzmaCell, Iran). Finally, the PCR product was sent to Sinaclon, Iran, for sequencing. 


\section{Evaluation of Antimicrobial Properties of Lactobacillus brevis \\ Preparation of Supernatant}

Purified Lactobacillus brevis was cultured on MRS broth and was incubated under anaerobic conditions at $37^{\circ} \mathrm{C}$ to obtain turbidity of $0.5 \mathrm{McF}$ arland. Then, to prepare the supernatant, the selected culture of Lactobacillus brevis was centrifuged at $4000 \mathrm{rpm}$ for 4 minutes, and then the supernatant was filtered using a 0.22-micron filter (23).

\section{Preparation of Pathogenic Bacteria}

Five strains of pathogenic bacteria, including Escherichia coli (ATCC 2592), Staphylococcus aureus (ATCC 25923), Salmonella typhimurium (ATCC 14028), Pseudomonas aeruginosa (ATCC 27853), and Enterococcus faecalis (ATCC 29212), were obtained from Pasteur Institute of Iran and cultured in Nutrient broth. Then they were used with turbidity equivalent to 0.5 McFarland (24).

\section{Antimicrobial Activity}

Mueller-Hinton agar (MHA) (Merck, Germany) medium was used to evaluate the antimicrobial activity of $L$. brevis. For this purpose, two agar well and disk diffusion methods were used. In both methods, the MRS Agar plate was a positive control for L. brevis growth $(25,26)$.

\section{Disk Diffusion Method}

The $6 \mathrm{~mm}$ diameter paper disks (Padtan Teb, Iran) were soaked in Lactobacillus brevis supernatant for 5 minutes, then placed at $37^{\circ} \mathrm{C}$ to dry completely. Selected pathogenic bacteria cultured in Nutrient broth (Liofilchem, Italy) McFarland 0.5 were cultured on Mueller-Hinton agar plate using a swab. The disk impregnated with $L$. brevis supernatant was then placed on the surface of the Mueller-Hinton agar medium. After 24 hours of incubation at $37^{\circ} \mathrm{C}$, the inhibitory zone diameter was measured (25).

\section{Agar Well Diffusion Method}

During this method, the suspension of pathogenic bacteria in nutrient broth medium ( 0.5 McFarland) was cultured on Mueller-Hinton agar medium with a sterile swab. Then, wells were made on the medium using a sterile Pasteur pipette, and $30 \mu \mathrm{L}$ of $L$. brevis supernatant was poured into the wells. After drying, the plates were incubated in a $37^{\circ} \mathrm{C}$ incubator for 24 hours. Then inhibition zone diameter created by $L$. brevis against each pathogenic bacterium was measured (26).

\section{Antibiotic Resistance}

In this study, antibiotics Vancomycin $(30 \mu \mathrm{g})$, Kanamycin $(30 \mu \mathrm{g})$, Gentamicin $(10 \mu \mathrm{g})$, Nalidixic acid (30 $\mu \mathrm{g})$, Ampicillin $(10 \mu \mathrm{g})$, Erythromycin (25 $\mu \mathrm{g})$, Tetracycline (30 $\mu \mathrm{g})$ (Padtan Teb, Iran) were used. To evaluate the resistance of $L$. brevis to the mentioned antibiotics, first, the desired strain with a density of 0.5 McFarland was cultured on MRS Agar medium. Then antibiotic discs with a specific density at a distance of $4 \mathrm{~cm}$ were placed on the plate surface. The plate was then incubated for 24 hours at $37^{\circ} \mathrm{C}$. After this period, the inhibition zone diameter around the disc was measured, resistance and sensitivity to the antibiotic were evaluated. Also, MRS Agar medium was used to culture the positive control strain $(27,28)$.

\section{Results}

A total of thirteen microorganisms were isolated, including gram-negative and gram-positive bacilli and cocci. Of these thirteen microorganisms, eight isolates were gram-positive bacilli. Six isolates tested negative for oxidase, catalase, indole, motility, and spore tests in this group and were considered as possible lactobacilli (Table 1).

Table 1. Morphological and biochemical characteristics of bacteria isolated from cottage cheese

\begin{tabular}{|cc|cccccc}
\hline Isolate & Morphology & Gram & Oxidase & Catalase & Indole & Motility & Spore \\
\hline PA1 & Bacilli & positive & - & - & - & - & - \\
PA2 & Bacilli & negative & + & + & - & + & - \\
PA3 & Bacilli & positive & - & - & - & - & - \\
PA4 & Cocci & positive & - & - & - & + & + \\
PA5 & Bacilli & positive & + & + & - & - & + \\
PA6 & Bacilli & positive & - & - & - & - & - \\
PA7 & Cocci & positive & - & + & + & - & - \\
PA8 & Bacilli & positive & + & + & - & - & - \\
PA9 & Cocci & positive & + & - & - & + & - \\
PA10 & Bacilli & positive & - & - & - & - \\
\hline
\end{tabular}




\begin{tabular}{rc|cccccc} 
Isolate & Morphology & Gram & Oxidase & Catalase & Indole & Motility & Spore \\
\hline PA11 & Bacilli & negative & + & - & + & - & - \\
PA12 & Bacilli & positive & - & - & - & - & - \\
PA13 & Bacilli & positive & - & - & - & - & - \\
\hline
\end{tabular}

\section{Sugar Consumption by Bacteria}

Carbohydrate fermentation experiments, the results of bacterial sugar consumption, and the ability to grow at temperatures 15 and $45^{\circ} \mathrm{C}$ are expressed in Table 2.

Based on the results of biochemical tests (Tables 1 and 2), the PA6 isolate was selected as L. brevis according to Bergey's Manual of Systematic Bacteriology.
Confirmation of Identification using PCR and Sequencing

To confirm the genus Lactobacillus, polymerase chain reaction (PCR) was used for the $16 \mathrm{~s}$ rRNA gene. The isolates were examined, and the formation of a $195 \mathrm{bp}$ band by electrophoresis was confirmed by the biochemical diagnosis (Figure 1).

Table 2. Fermentation of carbohydrate test results

\begin{tabular}{|ccccccccc} 
Isolate & Arabinose & Cellobiose & Melezitose & Melibiose & Raffinose & Ribose & Sucrose & $\begin{array}{c}\text { Growth } \\
\text { temperature } \\
15 / 45\end{array}$ \\
PA1 & - & + & + & - & - & + & + & $+/-$ \\
PA3 & + & + & - & + & + & + & + & $-/+$ \\
PA6 & - & + & + & - & - & + & + & $+/-$ \\
PA10 & + & - & + & + & + & + & + & $-/+$ \\
PA12 & - & + & + & - & - & + & + & $+/-$ \\
PA13 & + & + & - & + & + & + & + & + \\
\hline
\end{tabular}

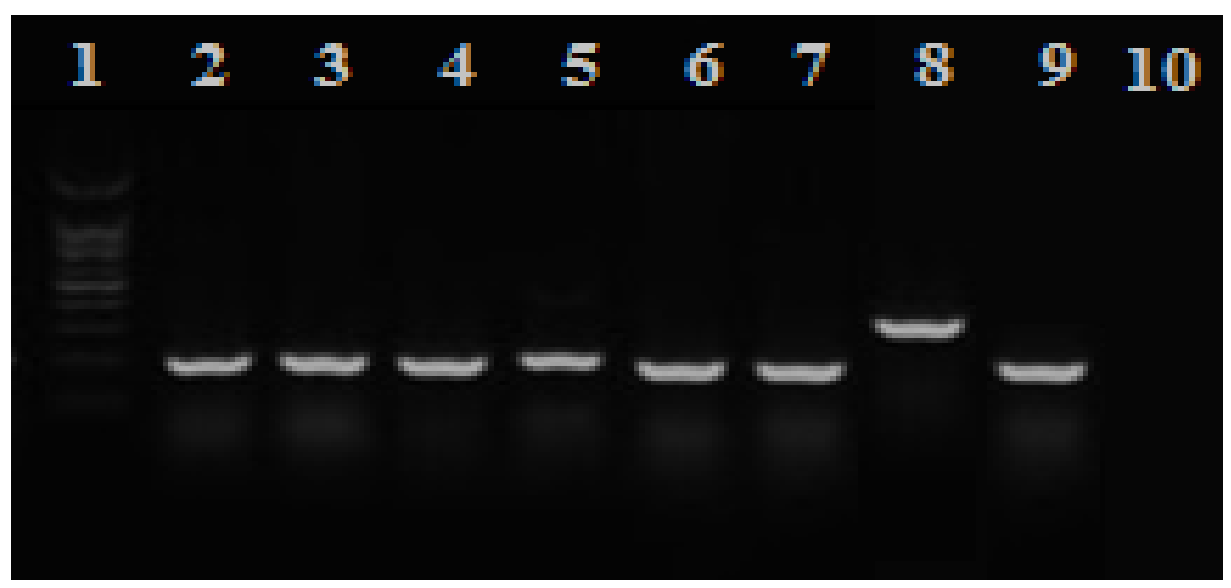

Figure 1. PCR test results. The six isolates had a band of $195 \mathrm{bp}$, which was confirmed as Lactobacillus. 1) 100bp Ladder 2-7) isolates with $195 \mathrm{bp}$ band as Lactobacillus 8) non-Lactobacillus with 350 bp band 9) Positive Control (Lactobacillus casei PTCC 1608) 10) negative control

\section{Sequencing}

PCR product of isolate PA6 was sent to Sinaclon for sequencing. The results of PCR product sequencing after comparing the sequences with the data in NCBI and BLAST analysis of the obtained sequence showed the similarity of PA6 isolate with L. brevis, which showed the confirmation of biochemical results and correct species detection (Figure 2). 


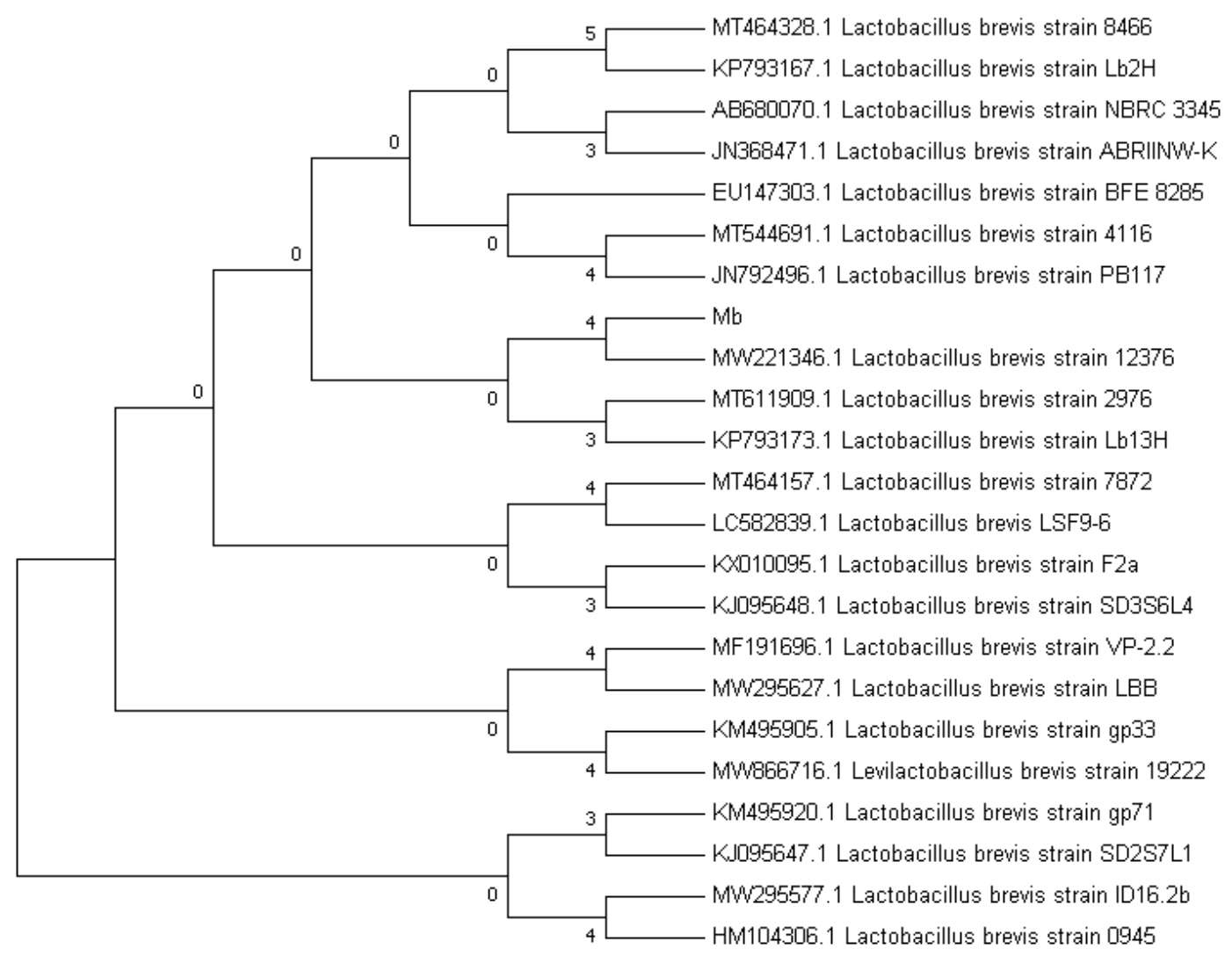

Figure 2. Phylogenetic tree of the selected Lactobacillus brevis

\section{Antibiotic Resistance}

The results of the antibiotic resistance test are demonstrated in Table 3. L. brevis was susceptible to Vancomycin and Gentamicin; this strain also was intermediate susceptible to Nalidixic acid and Kanamycin and was susceptible to Erythromycin and Kanamycin, Tetracycline, Ampicillin, and Chloramphenicol.

Table 3. Resistance of Lactobacillus brevis isolates against some common antibiotics

\begin{tabular}{|c|c|c|c|c|c|c|c|c|}
\hline Strain & Erythromycin & Kanamycin & Tetracycline & $\begin{array}{l}\text { Nalidixic } \\
\text { acid }\end{array}$ & Gentamicin & Ampicillin & Chloramphenicol & Vancomycin \\
\hline $\begin{array}{c}\text { Lactobacillus } \\
\text { brevis }\end{array}$ & S & 1 & S & 1 & $\mathrm{R}$ & $\mathrm{S}$ & $S$ & $\mathrm{R}$ \\
\hline
\end{tabular}

\section{Investigation of Antimicrobial Activity}

The antimicrobial activity of $L$. brevis supernatant against five pathogenic strains was investigated by the disk and well diffusion methods (Figures 3 and $\underline{4}$ ). The results showed that the inhibitory ability varied from 9 to $19 \mathrm{~mm}$. In both methods, the highest inhibitory effect was on the bacterium Salmonella typhimurium, a gram-negative bacterium and the cause of one of the most common food poisonings, and the least inhibitory effect was on Enterococcus faecalis, which is a gram-positive facultative anaerobic bacterium.

The results of the well diffusion method in (Figure 3) show the favorable inhibitory effect of $L$. brevis.
During this method, the highest inhibitory effect was against S. typhimurium with inhibition of $19 \mathrm{~mm}$, and the lowest inhibitory effect against $E$. faecalis with inhibition of $11 \mathrm{~mm}$.

The results obtained in the disk diffusion method (Figure 4) show the inhibitory effect of L. brevis. During this method, the highest inhibitory effect was against S. typhimurium with inhibition of $16 \mathrm{~mm}$, and the lowest inhibitory effect was against $E$. faecalis with inhibition of $9 \mathrm{~mm}$. 


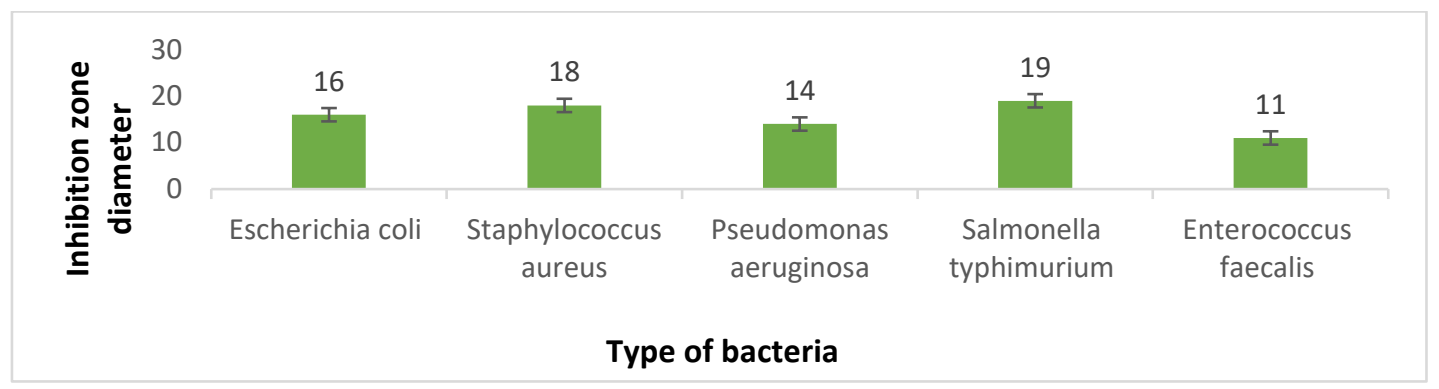

Figure 3. Inhibition zone diameter against pathogenic bacteria using well diffusion method

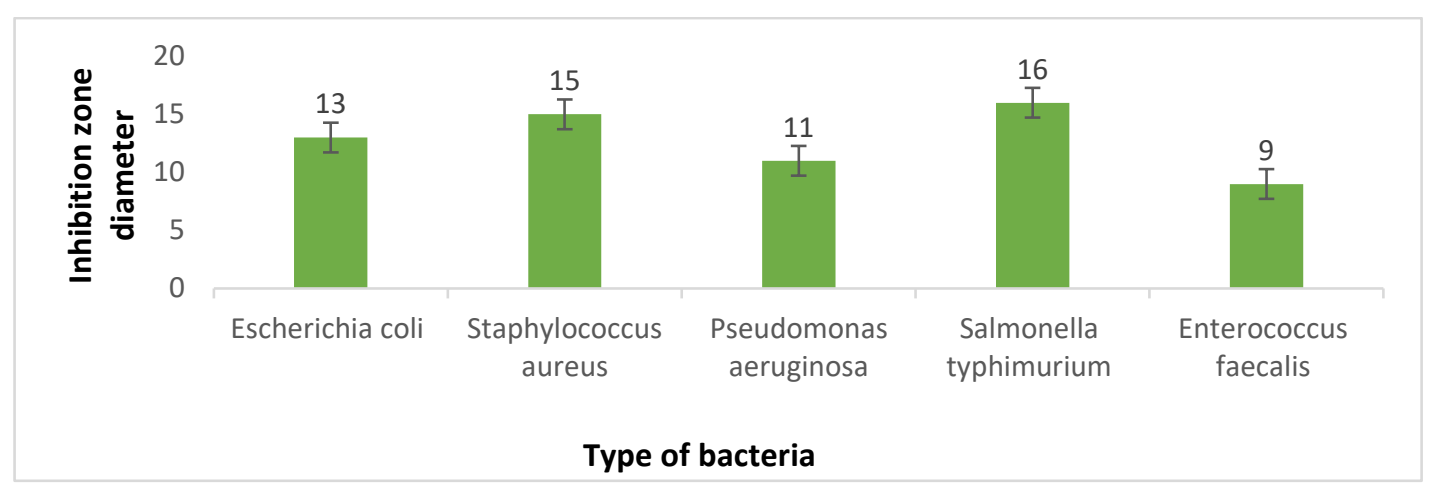

Figure 4. Inhibition zone diameter against pathogenic bacteria by disk diffusion method

\section{Discussion}

The diversity of Lactobacillus in food products and different geographical conditions is so great that this diversity in dairy products in the world is complex and widespread. For this reason, more research should be done to achieve suitable strains with specific functional characteristics (29-31). Cheese is one of the dairy products widely available in hundreds of different types (32). The cheese made in Bazoft is one of the types of cheese that has been little studied. Therefore, it is a good source for isolating microbial strains. MRS medium has been used to isolate lactobacilli in different sources. Identification of lactic acid bacteria is based on biochemical, morphological, and molecular properties $(33,34)$.

The first part of this study was about the morphological and biochemical identification of $L$. brevis and its isolation from cottage cheese. Then, the molecular method was used to confirm biochemical tests (22). According to our findings, the rod-shaped bacteria with diverse cell arrangements, grampositive, catalase-negative, and non-spores, belong to the genus Lactobacillus from the lactic acid family. In this study, all isolates could not produce gas from glucose, so they were placed in the category of Facultatively Heterofermentative Lactobacilli. Isolates that grew at $15^{\circ} \mathrm{C}$ and could not grow at $45^{\circ} \mathrm{C}$ are also classified as mesophilic microorganisms $(19,20)$. According to Bergey's Manual of Systematic Bacteriology, L. brevis can ferment the sugars Arabinose, Maltose, Ribose, Melibiose, and Sucrose but can also not ferment Mannose Melezitose (21). Based on this, L. brevis was isolated from the cottage cheese and then confirmed by the molecular method. In this study, six bacteria out of 10 isolates from cottage cheese were identified as Lactobacillus, including two isolates of Lactobacillus plantarum, two isolates of Lactobacillus casei, one isolate of Lactobacillus fermentum, and one isolate of L. brevis.

In the study of Hejazi et al. in 2012, 8 out of 22 isolates were identified as Lactobacillus, which included five species of Lactobacillus plantarum, two species of Lactobacillus brevis, and one species of Lactobacillus casei (35). In 2014, Singh and Singh isolated several Lactobacillus species, including $L$. plantarum, Lactobacillus paracasei, Lactobacillus rhamnosus, Lactobacillus curvatus, and L. brevis, from ripped cheddar cheese (36).

In 2019, Abdali et al. identified 10 isolates from traditional Iranian cheese as Lactobacillus, of which six species were $L$. plantarum and the others were Lactobacillus paracasei, Lactobacillus acidophilus, $L$. brevis, and Lactobacillus buchneri (37). In 2020, Zhang et al. isolated a total of 18 bacteria as Lactobacillus from cheese, including 5 isolates of $L$. plantarum, four isolates of $L$. brevis, two isolates of Lactobacillus fermentum, three isolates of $L$. rhamnosus, three isolates of Lactobacillus furfuricola, and one isolate of L. paracasei (38). 
The second part of this study was about the antimicrobial properties of $L$. brevis. Searching for safe, natural, and accessible antimicrobials has always been of interest to researchers. On the other hand, Lactobacillus bacteria are GRAS due to their antimicrobial properties and non-pathogenicity and can be an excellent alternative to use as antimicrobials (3941). Lactobacilli form a significant part of the natural intestinal flora of animals and humans (42). They produce various antimicrobials such as Organic acids, Diacetyl, Acetone, Hydrogen peroxide, Retr-ocyclin, Antifungal peptides, and Bacteriocin. Inhib-ition of pathogenic activity by these bacteria can play an essential role in the health of individuals by combating infections caused by common pathogens of the gastrointestinal tract (43). It also prevents the growth of spoilage and food poisoning microorg-anisms, increasing the durability and the safety of food products (44). In this study, the well diffusion method had better and more positive results than the disk diffusion method, and L. brevis showed better inhibitory effects in the well diffusion method. L. brevis supernatant showed the highest inhibitory effect by well diffusion method against Salmonella Typhimurium with a growth inhibition zone of $19 \mathrm{~mm}$ and the least inhibitory effect by disk diffusion method with a growth inhibition zone of $9 \mathrm{~mm}$ against $E$. faecalis.

In a 2017 study by Azizi et al., the effect of antimicrobial compounds produced by $L$. brevis isolates against three bacteria, $S$. aureus (ATCC 25923), Listeria innocua (ATCC 33090), and Escherichia coli (ATCC 25922), was evaluated. The most susceptible and resistant bacteria to antimicrobial compounds produced by Lactobacillus brevis were $S$. aureus and Listeria innocua, respectively (45). Jabberi et al. in 2017 evaluated the antimicrobial activity of L. brevis isolated from cottage cheese made in pottery against S. aureus (ATCC 25923), Staphylococcus epidermidis (ATCC 12228), S. typhimurium (ATCC 19430), and E. coli (ATCC 25922) using well diffusion method. The results of their study showed that the largest and smallest growth inhibition zones were observed against S. aureus and E. coli, respectively (46). In 2020, Hojjati et al. examined the antagonistic activities and safety properties of $L$. brevis isolated from traditional Iranian cheese. In this study, the antibacterial effect of L. brevis against pathogenic strains of $S$. aureus (ATCC 25923), Pseudomonas aeruginosa (PTCC 1707), S. typhimurium (PTCC 1609), and E. coli (ATCC 25922) was evaluated. The results showed that the most susceptible species were $S$. aureus, and the most resistant species was $S$. typhimurium (47).

The third part of this study was about the susceptibility of $L$. brevis to common antibiotics. The mechanism of how antibiotics affect bacteria is different. The antibiotics Vancomycin and Ampicillin destroy the cell wall, Tetracycline and Chloramphenicol inhibit protein synthesis, and Penicillin affects cell permeability. In a 2011 report by Kirtzalidou et al., the strains of L. brevis, L. plantarum, and Lactobacillus curvatus were resistant to Vancomycin (48). In a 2014 study by Shazali et al., L. brevis was resistant to Ciprofloxacin, Tetracycline, and Vancomycin (49). A study by Falah et al. in 2019 showed that L. brevis is resistant to Vancomycin and Gentamicin and is susceptible to Ampicillin, Chloramphenicol, and Kanamycin (50). Otaghsara et al. in 2020 reported that the $L$. brevis strain is resistant to Vancomycin and intermediate susceptible to the Tetracycline and Streptomycin antibiotics (51). In this study, the resistance of $L$. brevis isolated from cottage cheese was distinct to different antibiotics. The results showed that $L$. brevis isolates were resistant to Vancomycin and Gentamicin, intermediate susceptible to Kanamycin and Nalidixic acid, and susceptible to Erythromycin, Ampicillin, Tetracycline, and Chloramphenicol.

\section{Conclusion}

Microorganisms' isolation from local sources is an effective way to obtain valuable strains with unique characteristics. In this study, Lactobacillus brevis isolated from the Bazoft cottage cheese had good antimicrobial properties against pathogenic bacteria. Also, antibiotic evaluation in L. brevis is necessary from a consumer safety perspective and can be considered to replace the lost microbial flora of the gastrointestinal tract during antibiotic therapy.

\section{Acknowledgment}

We would like to express our gratitude and thanks to all those who helped us during this research.

\section{Funding}

This article was done without organizational financial support.

\section{Conflict of Interest}

There is no conflict between the authors of the article.

\section{Reference}

1. Stanley G. Microbiology of fermented milk products. Int J Dairy Technol. 1998:50-79.

2. Belewu M, Aina O. Microbial evaluation of indigenous milk products with special reference to the bacterial flora of some public health importance. Afr J Microbiol. 2000;1(1):13-9.

3. Siso MG. The biotechnological utilization of cheese whey: a review. Bioresour Technol. 1996;57(1):1-11. 8524(96)00036-3] 
4. Garabal JI, Rodríguez-Alonso P, Centeno JA. Characterization of lactic acid bacteria isolated from raw cows' milk cheeses currently produced in Galicia (NW Spain). LWT - Food Sci Technol. 2008;41(8):1452-8. [DOI:10.1016/i.lwt.2007.09.004]

5. Ahamdi S, Khamiri M, Khosroshahi A, Kashani Negad M. Isolation and identification of Lacic acid bacteria from Lighvan cheeses. J Agric Nat Resour. 2008;3(16):80-91.

6. Ghotbi M, Soleymaniyan Zad S, Sheikh Zeinoddin M. Identification of facultative hetrofermentive in Lighvan cheese. Iranian Food Science Technology. 6 (2): 145-148. Farci; 2010.

7. Gilliland SE. Health and nutritional benefits from lactic acid bacteria. FEMS Microbiol Rev. 1990;7(1-2):175-88. [DOI:10.1111/j.15746968.1990.tb04887.x] [PMID]

8. De Roos NM, Katan MB. Effects of probiotic bacteria on diarrhea, lipid metabolism, and carcinogenesis: a review of papers published between 1988 and 1998. Am J Clin Nutr. 2000;71(2):405-11.

[DOI:10.1093/ajcn/71.2.405] [PMID]

9. Vancanneyt M, Naser SM, Engelbeen K, De Wachter M, Van der Meulen R, Cleenwerck I, et al. Reclassification of Lactobacillus brevis strains LMG 11494 and LMG 11984 as Lactobacillus parabrevis sp. nov. Int J Syst Evol Microbiol. 2006;56(7):1553-7. [DOI:10.1099/ijs.0.64215-0] [PMID]

10. Ilayaraja R. Antimicrobial activity and characterization of Lactobacillus reuteri isolated from human milk. Indian J Med Sci. 2010;3 $(1 / 2): 27-33$.

11. Klaenhammer TR. Bacteriocins of lactic acid bacteria. Biochimie. 1988;70(3):337-49. [DOI:10.1016/0300-9084(88)90206-4]

12. Martens E, Demain AL. The antibiotic resistance crisis, with a focus on the United States. J Antibiot (Tokyo). 2017;70(5):520-6. [DOI:10.1038/ja.2017.30] [PMID]

13. AFRC RF. Probiotics in man and animals. J Appl Microbiol. 1989;66(5):365-78. [DOI:10.1111/j.1365-2672.1989.tb05105.x]

14. Arqués JL, Rodríguez E, Langa S, Landete JM, Medina M. Antimicrobial activity of lactic acid bacteria in dairy products and gut: effect on pathogens. Biomed Res Int. 2015;2015. [DOI:10.1155/2015/584183] [PMID] [PMCID]

15. Cizeikiene D, Juodeikiene G, Paskevicius A, Bartkiene E. Antimicrobial activity of lactic acid bacteria against pathogenic and spoilage microorganism isolated from food and their control in wheat bread. Food Control.
2013;31(2):539-45

[DOI:10.1016/j.foodcont.2012.12.004]

16. Ehsani A, Mahmoudi R, Hashemi M, Raeisi M. Identification of Lactobacillus species isolated from traditional cheeses of west Azerbaijan. Iran J Med Microbiol 2014;8(1):38-43.

17. Rokhtabnak N, Khaleghi M, Sasan HA. Isolation and identification of Lactobacillus bacteria with probiotic potential from traditional dairy in Kerman. Iran J Med Microbiol. 2016;10(1):2434.

18. Nouri S, Nazeri S, Hosseyni P. Biochemical and molecular identification of probiotic bacteria. JCMR. 2018;31(1):106-13.

19. Bhardwaj A, Puniya M, Sangu K, Kumar S, Dhewa T. Isolation and biochemical characterization of Lactobacillus species isolated from Dahi. RRJoDST. 2012;1:18-31.

20. Zimina MI, Prosekov AJ, Babich OO, Sukhih SA. Identification and studying of the biochemical properties of lactobacillus strains. Life Sci. 2014;11(11):338-41.

21. Kandler O aWNGLJH, N.S. Nair, M.E. Sharpe Bergey's Manual of Systematic Bacteriology. 8th ed ed1986.

22. Dubernet S, Desmasures N, Guéguen M. A PCRbased method for identification of lactobacilli at the genus level. FEMS Microbiol Lett. 2002;214(2):271-5. [DOI:10.1111/j.15746968.2002.tb11358.x] [PMID]

23. Mahdi LH, Husain SN. Antagonstic Effect of Lactobacillus Fermentum Supernatant AgainstEnterococcus Faeciumand Enterococcus Faecalis In Vitro. Journal of the Faculty of Medicine Baghdad. 2012;54(2):154-7.

24. Bibalan MH, Eshaghi M, Rohani M, Pourshafie MR, Talebi M. Determination of bacteriocin genes and antibacterial activity of lactobacillus strains isolated from fecal of healthy individuals. Int J Mol Cell Med. 2017;6(1):50.

25. Tajehmiri A, Darsanaki RK, Moslem MN, Lozoumi Z, Kolavani MH, Aliabadi MA. Antimicrobial Activity of Lactobacillus spp Isolated from Commercial Yoghurts against Pathogenic Bacteria. J Appl Microbiol. 2014;8:2211-5.

26. Shokraei SS, Rahimifard N, Shad MM. Comparison Of Three Methods For Evaluation Of The Antimicrobial Activity Of Lactobacillus Acidophilus Bacteria Againstescherichia Coli And Salmonella Enterica Serotype Enteritidis. Iran J Public Health. 2014;43(2):167.

27. Caglar E, Kargul B, Tanboga I. Bacteriotherapy and probiotics' role on oral health. Oral Dis. 
2005;11(3):131-7. 0825.2005.01109.x] [PMID]

28. Jomehzadeh N, Javaherizadeh H, Amin M, Saki M, Al-Ouqaili MTS, Hamidi H, et al. Isolation and identification of potential probiotic Lactobacillus species from feces of infants in southwest Iran. Int J Infect Dis. 2020;96:524-30. [DOI:10.1016/j.ijid.2020.05.034] [PMID]

29. Hashemi SM, Shahidi F, Mortazavi SA, Milani E, Eshaghi Z. Potentially probiotic Lactobacillus strains from traditional Kurdish cheese. Probiotics Antimicrob Proteins. 2014;6(1):22-31. [DOI:10.1007/s12602-014-9155-5] [PMID]

30. Vinderola C, Reinheimer J. Culture media for the enumeration of Bifidobacterium bifidum and Lactobacillus acidophilus in the presence of yoghurt bacteria. Int Dairy J. 1999;9(8):497-505. [DOI:10.1016/S0958-6946(99)00120-X]

31. Coeuret V, Dubernet S, Bernardeau M, Gueguen $\mathrm{M}$, Vernoux JP. Isolation, characterisation and identification of lactobacilli focusing mainly on cheeses and other dairy products. Le Lait. 2003;83(4):269-306.

[DOI:10.1051/lait:2003019]

32. Campbell-Platt G. Fermented foods-a world perspective. Int Food Res J. 1994;27(3):253-7. [DOI: 10.1016/0963-9969(94)90093-0]

33. De Man J, Rogosa d, Sharpe ME. A medium for the cultivation of lactobacilli. J Appl Microbiol. 1960;23(1):130-5. [DOI:10.1111/j.13652672.1960.tb00188.x ]

34. Colombo M, de Oliveira AE, de Carvalho AF, Nero LA. Development of an alternative culture medium for the selective enumeration of Lactobacillus casei in fermented milk. Food Microbiol. 2014;39:89-95. [DOI:10.1016/j.fm.2013.11.008] [PMID]

35. Hejazi m, mokhtari zp, khosroushahli m, barzegari a, lotfi h, eslami s, et al. Factors affecting the performance of an apple and kiwifruit electronic grading system. 2012.

36. Singh S, Singh R. Phenotypic and genotypic characterization of non-starter Lactobacillus species diversity in Indian Cheddar cheese. LWT - Food Sci Technol. 2014;55(2):415-20. [DOI: 10.1016/j.lwt.2013.09.018]

37. Abdali H, Saei-Dehkordi SS, Mobini-Dehkordi M, Abtahi-Froushani SM. First Isolation and Molecular Detection of Autochthonous Potential Probiotic Lactobacilli Isolates from Iranian Traditional Poosti Cheese and their Antioxidative Activity. BJM. 2020;8(32).

38. Zhang X, Esmail GA, Alzeer AF, Arasu MV, Vijayaraghavan P, Choi KC, et al. Probiotic characteristics of Lactobacillus strains isolated from cheese and their antibacterial properties against gastrointestinal tract pathogens. Saudi J Biol Sci. 2020;27(12):3505-13. [PMID] [PMCID] [DOI:10.1016/j.sjbs.2020.10.022]

39. Santos A, San Mauro M, Sanchez A, Torres JM, Marquina D. The antimicrobial properties of different strains of Lactobacillus spp. isolated from kefir. Syst Appl Microbiol. 2003;26(3):4347. [DOI:10.1078/072320203322497464] [PMID]

40. Carasi P, Diaz M, Racedo SM, De Antoni G, Urdaci MC, Serradell Mde L. Safety characterization and antimicrobial properties of kefir-isolated Lactobacillus kefiri. Biomed Res Int. 2014;2014:208974. [PMID] [PMCID] [DOI:10.1155/2014/208974]

41. Forestier C, De Champs C, Vatoux C, Joly B. Probiotic activities of Lactobacillus casei rhamnosus: in vitro adherence to intestinal cells and antimicrobial properties. Res Microbiol. 2001;152(2):167-73. [DOI:10.1016/S09232508(01)01188-3]

42. Million M, Angelakis E, Paul M, Armougom F, Leibovici L, Raoult D. Comparative metaanalysis of the effect of Lactobacillus species on weight gain in humans and animals. Microb Pathog. 2012;53(2):100-8.

[DOI:10.1016/j.micpath.2012.05.007] [PMID]

43. Campana R, van Hemert S, Baffone W. Strainspecific probiotic properties of lactic acid bacteria and their interference with human intestinal pathogens invasion. Gut Pathog. 2017;9(1):1-12. [DOI:10.1186/s13099-0170162-4] [PMID] [PMCID]

44. Abriouel H, Pérez Montoro B, Casado Muñoz MdC, Knapp CW, Gálvez A, Benomar N. In silico genomic insights into aspects of food safety and defense mechanisms of a potentially probiotic Lactobacillus pentosus MP-10 isolated from brines of naturally fermented Aloreña green table olives. PLoS One. 2017;12(6):e0176801. [DOI:10.1371/journal.pone.0176801] [PMID] [PMCID]

45. Azizi F, Habibi Najafi MB, Edalatian Dovom MR. The biodiversity of Lactobacillus spp. from Iranian raw milk Motal cheese and antibacterial evaluation based on bacteriocin-encoding genes. AMB Express. 2017;7(1):176. [PMID] [PMCID] [DOI:10.1186/s13568-017-0474-2]

46. Jabbari V, Khiabani MS, Mokarram RR, Hassanzadeh AM, Ahmadi E, Gharenaghadeh S, et al. Lactobacillus plantarum as a probiotic potential from kouzeh cheese (traditional Iranian cheese) and its antimicrobial activity. Probiotics Antimicrob. 2017;9(2):189-93. [DOI:10.1007/s12602-017-9255-0] [PMID] 
47. Hojjati M, Behabahani BA, Falah F. Aggregation, adherence, anti-adhesion and antagonistic activity properties relating to surface charge of probiotic Lactobacillus brevis gp104 against Staphylococcus aureus. Microb Pathog. 2020;147:104420.

[DOI:10.1016/j.micpath.2020.104420] [PMID]

48. Kirtzalidou E, Pramateftaki P, Kotsou M, Kyriacou A. Screening for lactobacilli with probiotic properties in the infant gut microbiota. Anaerobe. 2011;17(6):440-3.

[DOI:10.1016/j.anaerobe.2011.05.007] [PMID]

49. Shazali N, Foo HL, Loh TC, Choe DW, Abdul Rahim R. Prevalence of antibiotic resistance in lactic acid bacteria isolated from the faeces of broiler chicken in Malaysia. Gut Pathog. 2014;6(1):1. [DOI:10.1186/1757-4749-6-1] [PMID] [PMCID]

50. Falah F, MORTAZAVI SA, TABATABAEI YF. Evaluation of probiotic properties of Lactobacillus brevis strain PML1 Based on the ability to adhesion to the epithelial cells of intestine. 2019.

51. Khanmohammadi Otaghsara O, Jamili S, Alipour M, Ghobadi S. Evaluation of probiotic properties and the antibacterial activity of lactic acid bacteria isolated from Rutilus kutum intestine. Iran J Fish Sci. 2020;19(6):3086-97. 


$$
\begin{aligned}
& \text { مجله ميكروبشناسى يزشكى ايران } \\
& \text { سال } 19 \text { ـ شماره ا - بهمن و اسفند ..1f }
\end{aligned}
$$

جداسازى و شناسايى لاكتوياسيلوس برويس از ينيرمحلى بازفت و ارزيابى فعاليت

\author{
ضد ميكروبى آن عليه برخى ميكرواركانيسمهاى بيماريزا

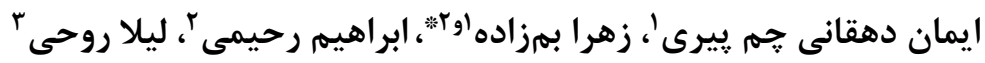

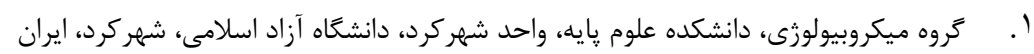

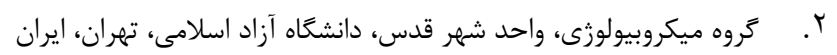

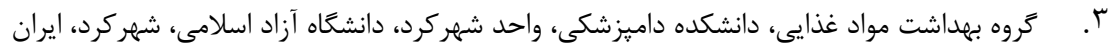

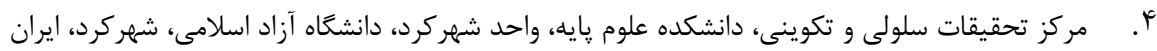

\section{جـكيده}

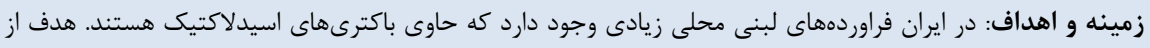

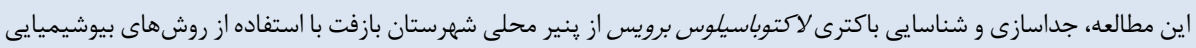

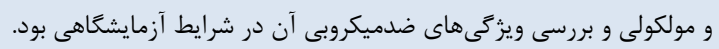

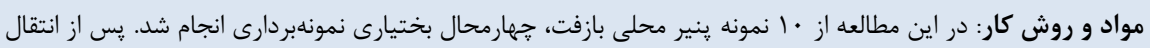

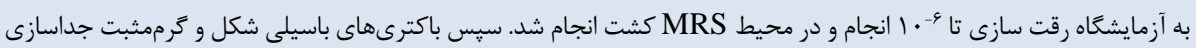

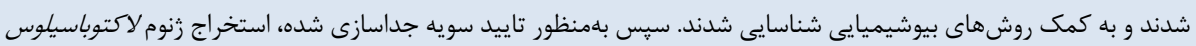

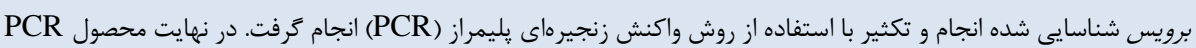

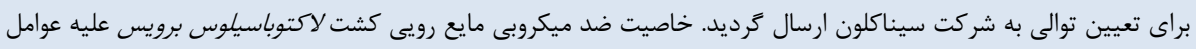

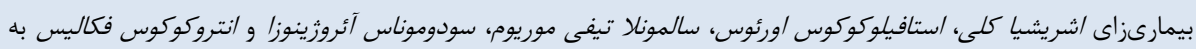

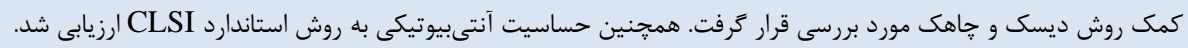

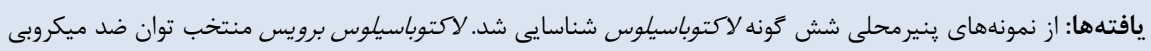

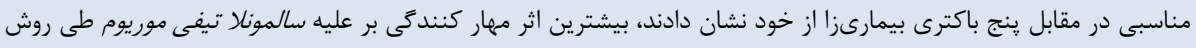

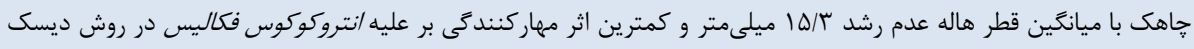

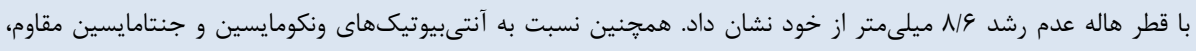

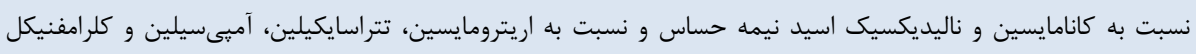
حساس بود. نتيجه كيرى: سويه لاكتوباسيلوس برويس جدا شده از ينير محلى بازفت توانايى ضدميكروبى مناسبى دارد و وبا انجام

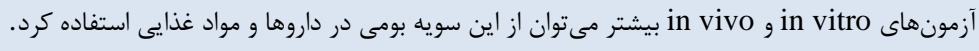

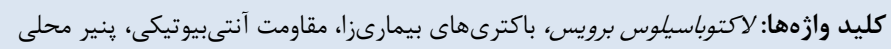

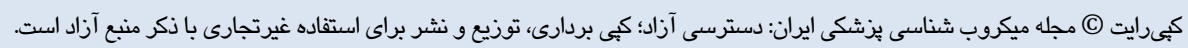

\section{اطلاعات مقاله}

تاريخجهُ مقاله

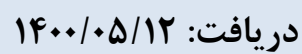

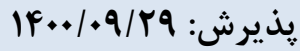

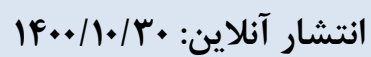

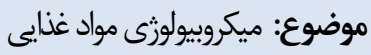

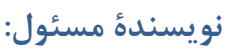

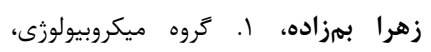

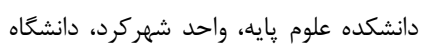

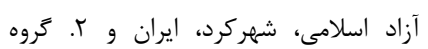

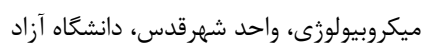
اسلامى، تهران، ايران

ايميل:

Bamzadehz@yahoo.com

(. مقدمه

(T). علت به وجود آمـدن ينيـر، انعقاد كازئين بالوسيلئ آنزيم رنين يا

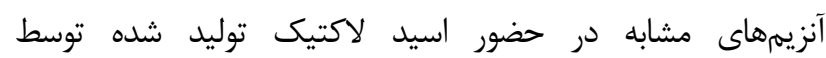

ميكروار گانيسمها است (ه).

باكترىهاى اسيد لاكتيك كـه در دوران رسـيدگى ينيـر محلى

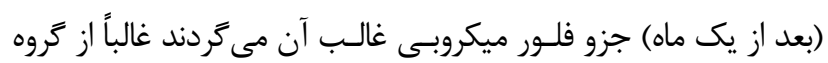

فراوردههاى لبنى تخميرى منبع مناسبى براى جداسازى

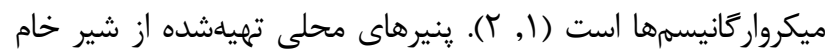

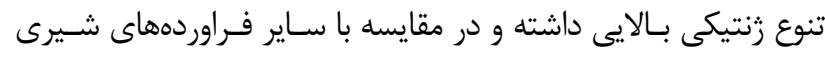

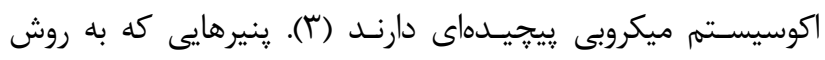
سنتى از شير خام توليد مىشوند داراى تنوع جنس ها، گونهها و فلور ميكروبى بومى شيرهايى است كه در تهيه اين نوع ينيرها به كار مىروند 
شد. نمونهها تحت شـرايط سـرد بــه آزمايشـعاه ميكروبيولوزىى

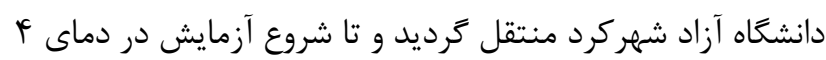

$$
\text { درجـه سلسيوس نكمهدارى شد. }
$$

\section{آماده سازى نمونهها وكشت اوليه}

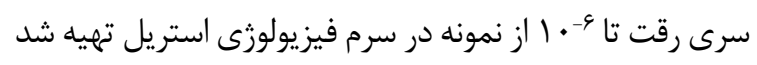

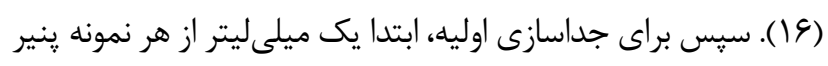

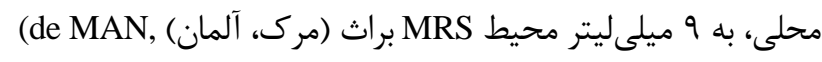
ROGOSA and SHARPE) مدت MF_F

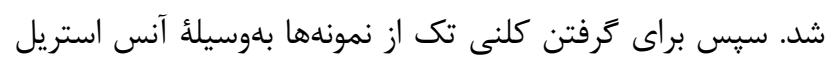

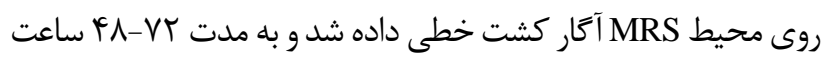

در دماى VY درجه سلسيوس كرمخانه كذارى شدند (IV)

\section{بررسى ريختشناسى}

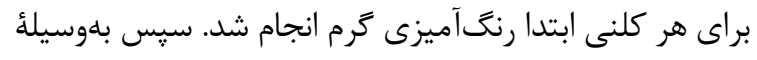

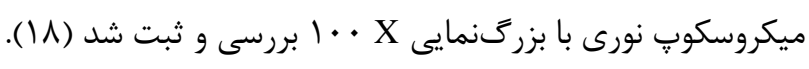

\section{بر رسى ويزگى هاى بيوشيميايى}

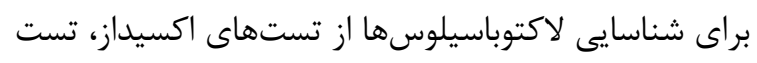
كاتالاز، تست حركت، تست اندول، تست اندوسيور، تست

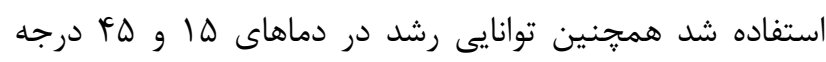

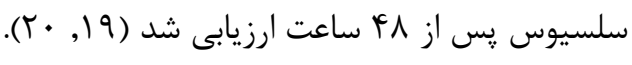

\section{تخمير كربوهيدراتها}

به اين منظور از محيط MRS بدون كربوهيدرات استفاده شد.

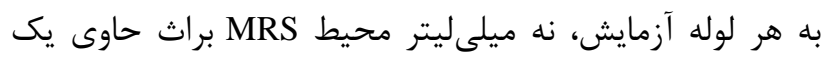

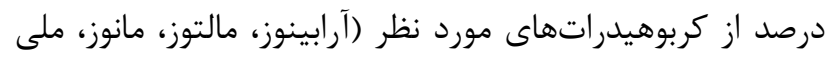

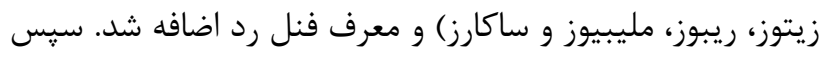

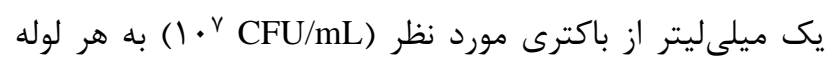

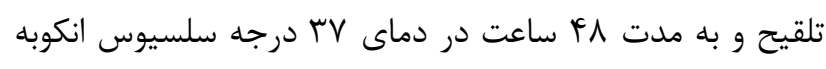

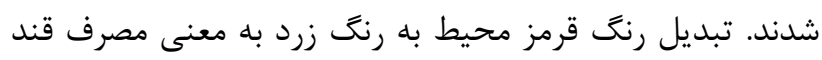

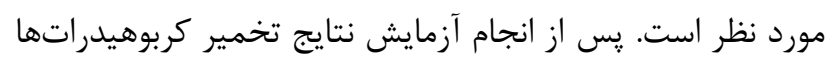
با جدول استاندارد برجى مقايسه شد ( آل).

\section{شناسايى مولكولى و توالىيابى}

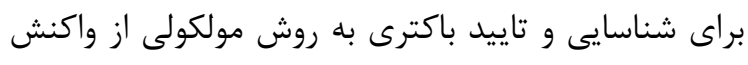

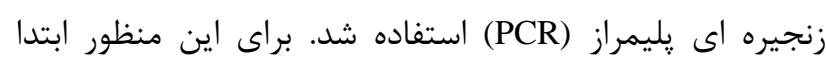

${ }^{2}$. Generally recognized as safe
هتروفر منتانيو اختيارى FHL) هستند (9) هاكترى هاى اسيد لاكتيك

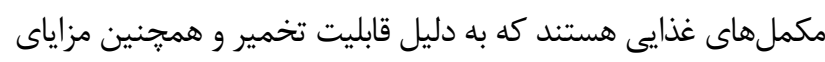

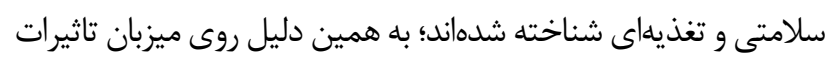

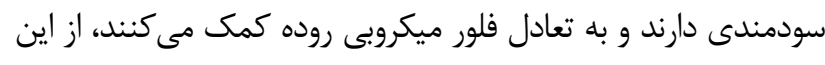

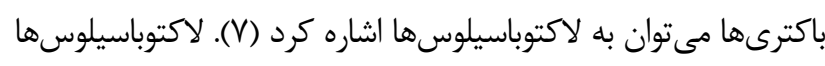

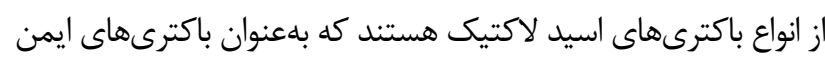

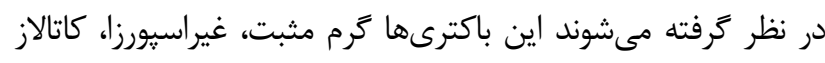

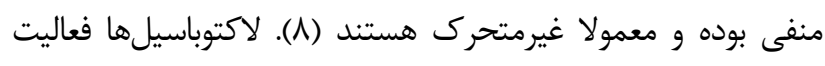

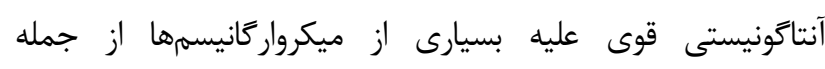

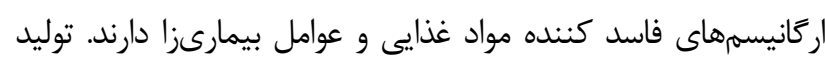

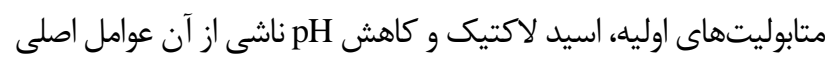

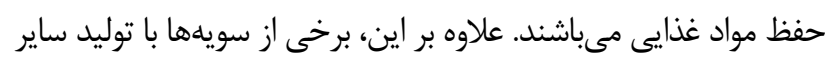

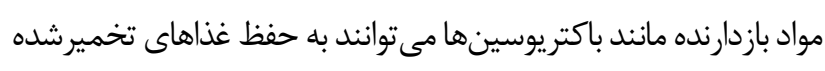

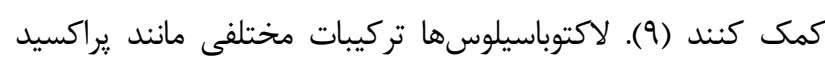
هيدروزن و اسيدهاى آلى را در طول تخميرهاى لاكتيك توليد مى كنيند

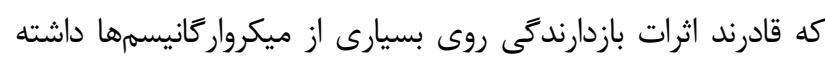

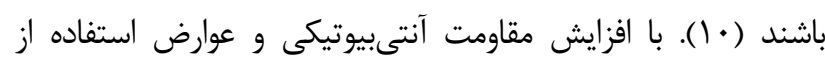

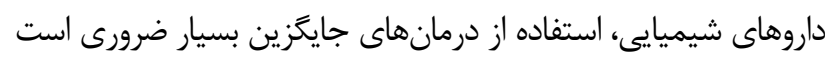

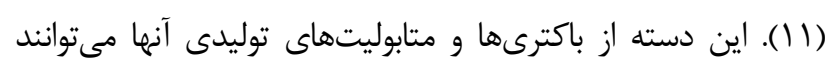

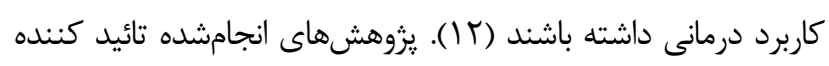

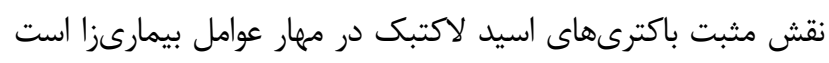

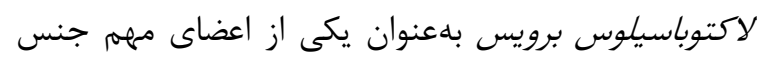

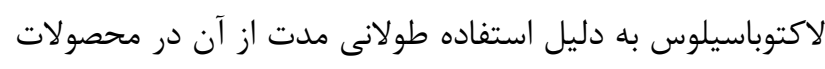

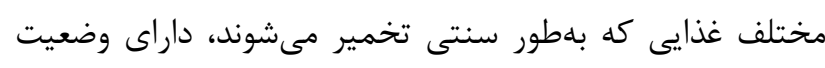

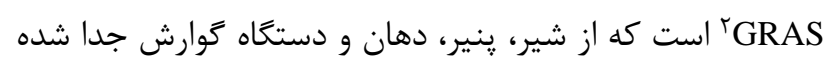

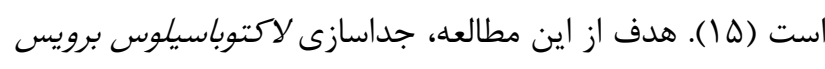

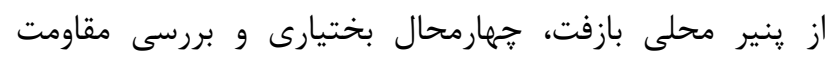

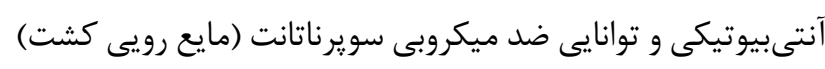
آن روى سويههاى بيمارىزاى باكتريايى است.

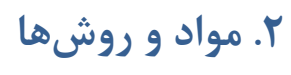

\section{نمونه}

در اين مطالعه •ا نمونه ينيـر محلـى بلهطور تصادفى از

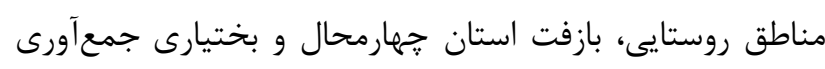

1. Facultative Heterofermentative Lactobacilli (FHL) 


\section{فعاليت ضد ميكروبى}

براى بررسى فعاليت ضد ميكروبى لاكتوباسيلوس برويس از مئروبى

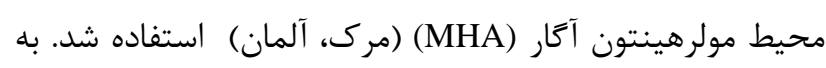

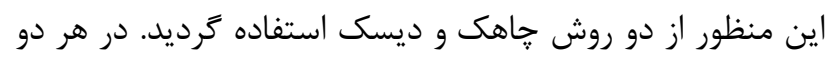

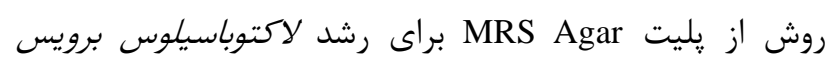
بهنوان كنترل مثبت استفاده شد (له ك, צY).

\section{روش ديسك}

ديسكهاى كاغذى (ياتن طب، ايران) به قطر و ميلىمتر در

مايع رويى (سويرناتانت) لاكتوباسيلوس برويس به مدي مدت له دقيقه إنه

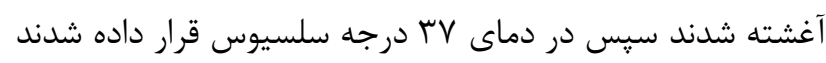
تا كاملا خشك شوند. باكترىهاى بيمارىزاى منتخب كشت داده

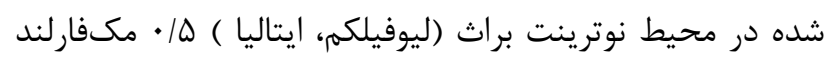
روى سطح يليت محيط مولر هينتون آكار (مرك، آلمان) با سواب

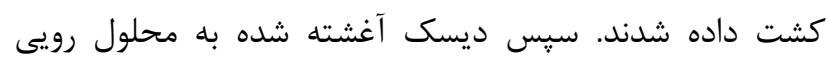
لاكتوباسيلوس برويس روى سطح محيط مولر هينتون آكار قرار

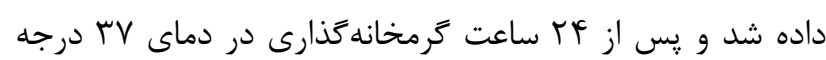

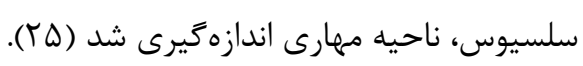

\section{روش جاهك}

طى اين روش از سوسيانسيون باكترىهاى بيمارىزاى كشت داده شده در محيط نوترينت براث (ه / • مك فارلند) با سوآي

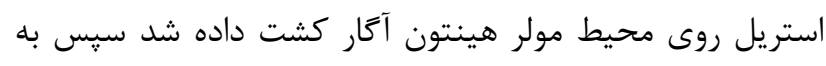

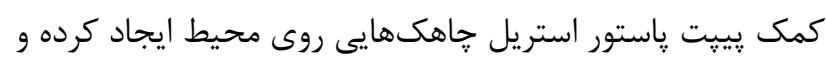

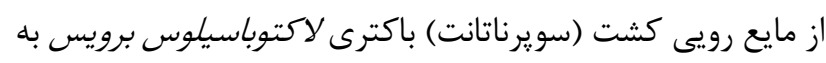

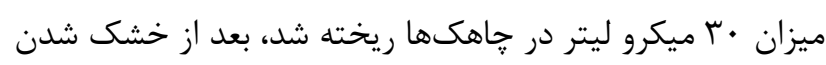

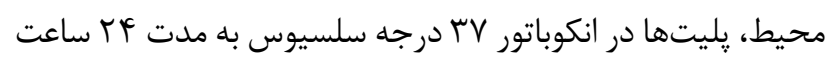
گرمخانه گذارى شدند. سيس قطر هاله عدم رشد ايجاد شده بهوسيله باكترى لاكتوباسيلوس برويس عليه هر يك از باكترى هاى

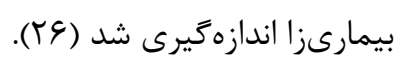

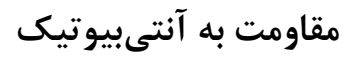

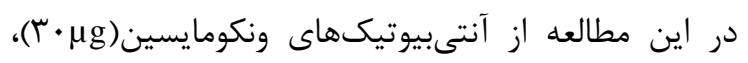

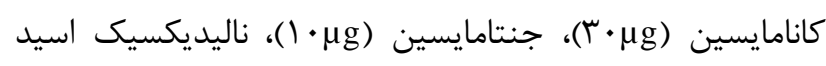

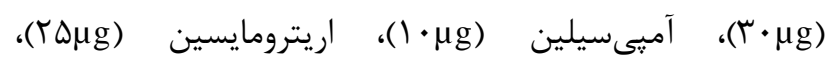

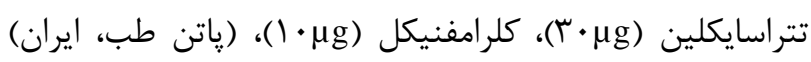
استفاده شد. بهمنظور بررسى مقاومت باكترى لاكتوباسيلوس (برى

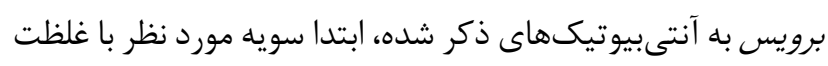

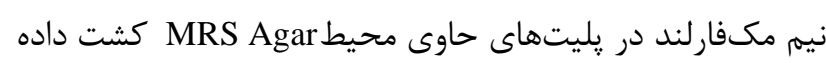

استخراج DNA از نمونه باكترى مطابق با يروتكل كيت استخراج DNA الخو براى واكنش PCR استفاده شد. از توالى آغازگر واكنش PCR

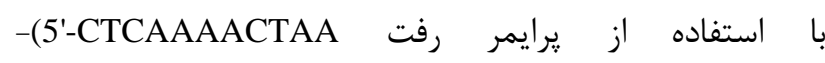

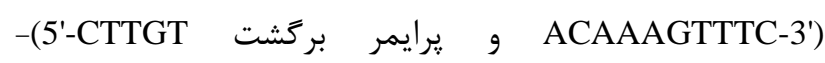
PCR استفاده شد (YT) ACACACC GCCCGTCA-3') در حجم ها ميكروليتر شامل / I I ميكروليتر بافر PCR با غلظت

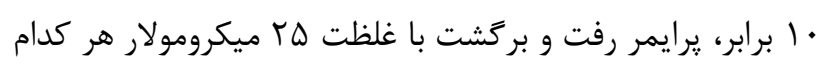
| • ميكروليتر، 1 ميكروليتر كلرايد منيزيم • •ه ميلى مولار، جهار

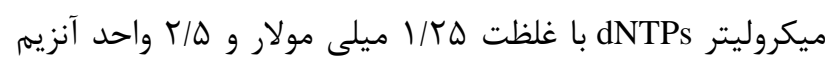
Taq DNA Polymerase شده، انجام گرفت. واكنش در دستگاه ترموسايكلـر (FlexCycler2،

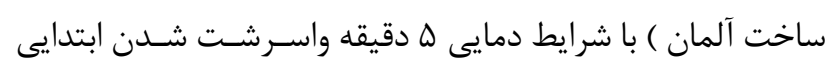

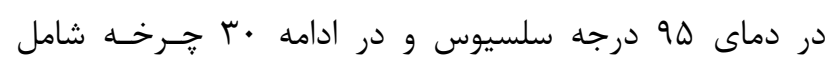

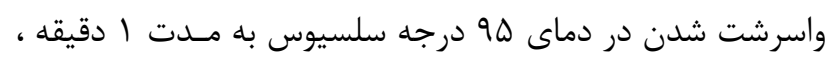

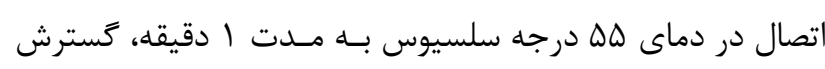

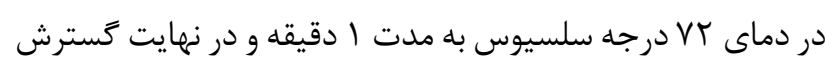
نهايى در دماى VT درجه سلسيوس بـه مدت · • إ دقيقه انجام شد.

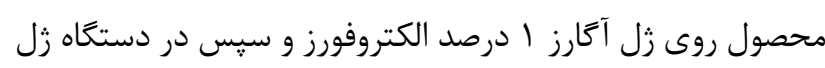
داك (آزماسل، ايران) بررسى شد. در نهايت محصول PCR براى توالى يابى به شركت سيناكلون، ايران ارسال خـرديـد.

\section{ارزيابى ويزَّى هاى ضدميكروبى لاكتوباسيلوس برويس \\ تهيه سويرناتانت}

لاكتوباسيلوس برويس خالص شده در محيط MRSMبراث، در شرايط بىهوازى و در دماى VV درجه سلسيوس گرمخانهگذارى شد تا كدورتى معادل ه/ • مكى فارلند بهدست آيد سيس بر براى تهيه

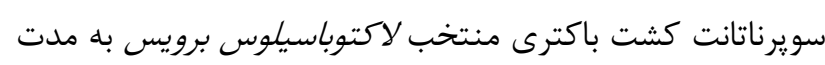

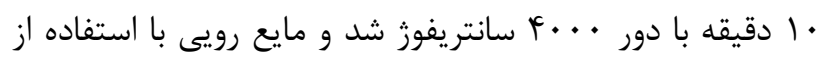

فيلتر r//• ميكرونى، فيلتر شد (Tr).

\section{آمادهسازى باكترىهاى بيمارىزا}

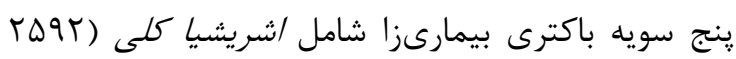

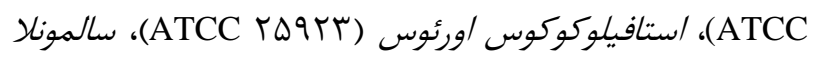

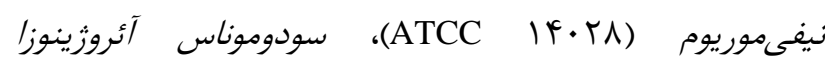
و انتروكوكوس فكاليس (ATCC rVADr) شركت زيست رويش تهيه و ويس كشت در محيط نوترينت براث با كدورتى معادل ه/ • مكفارلند مورد استفاده قرار گرفتند (YF). 


\section{مصرف قند بلووسيلة باكترىها}

آزمايش تخمير كربوهيبدرات، نتايج استفاده باكترىها از

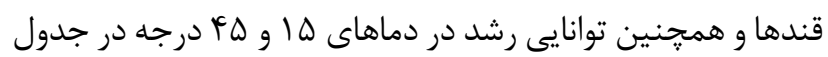

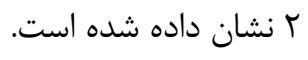

با توجه به نتايج بهدستآمده از آزمونهاى بيوشيميايى

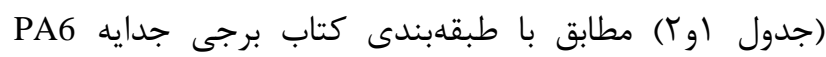

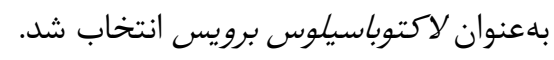

\section{تاييد شناسايى با استفاده از PCR و توالى يابى}

براى تاييد جنس لاكتوباسيلوس از طريق واكنش زنجيره

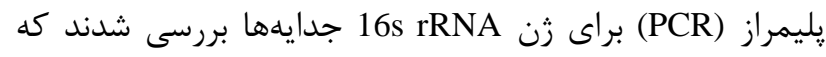

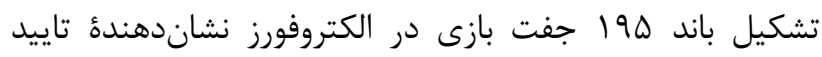
تشخيص بيوشيميايى بود (شكل () ) .
و سبس ديسكهاى آنتىبيوتيك با غلظت مشخص را در فاصله f

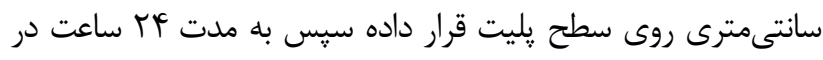

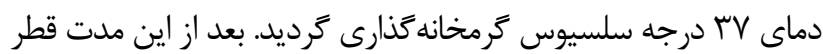

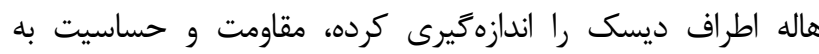

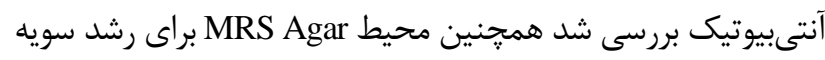

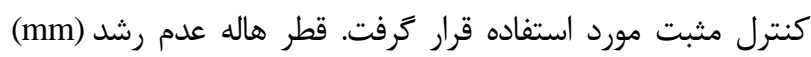

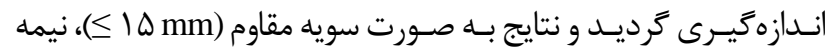

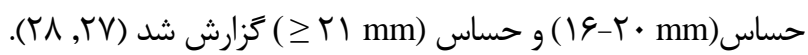

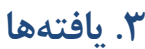

در مجموع سيزده ميكروار كانيسم جداسازى شد كه شامل باسيل و كوكوسىهاى كرم منفى و كرم مثبت بودند. در اين سيزده

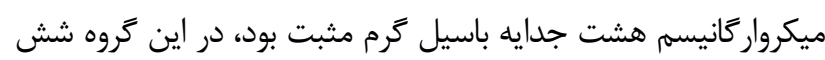

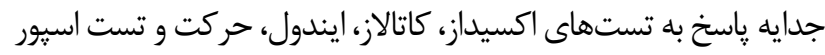
منفى بود و باعنوان لاكتوباسيل احتمالى درنظر گَرفته شد (جدول ( ).

جدول ا. ويثَى هاى ريخت شناسى و بيوشيميايى باكترىهاى جدا شده از ينيرمحلى

\begin{tabular}{|c|c|c|c|c|c|c|c|}
\hline اسبور & حركت & ايندول & كاتالاز & اكسيداز & كرم & شكل & جدايه \\
\hline- & - & - & - & - & مثبت & باسيل & PA1 \\
\hline- & + & - & + & + & منفى & باسيل & PA2 \\
\hline- & - & - & - & - & مثبت & باسيل & PA3 \\
\hline+ & + & - & - & - & مثبت & كوكسى & PA4 \\
\hline+ & - & - & + & + & مثبت & باسيل & PA5 \\
\hline- & - & - & - & - & مثبت & باسيل & PA6 \\
\hline - & - & + & + & - & مثبت & كو كسى & PA7 \\
\hline - & - & - & + & + & مثبت & باسيل & PA8 \\
\hline - & + & - & - & + & مثبت & كوكسى & PA9 \\
\hline- & - & - & - & - & مثبت & باسيل & PA10 \\
\hline- & - & + & - & + & منفى & باسيل & PA11 \\
\hline- & - & - & - & - & مثبت & باسيل & PA12 \\
\hline- & - & - & - & - & مثبت & باسيل & PA13 \\
\hline
\end{tabular}

جدول r. نتايج مربوط به آزمون تخمير كربوهيدراتها

\begin{tabular}{|c|c|c|c|c|c|c|c|c|}
\hline دماى رشاء 1 هاء & ساكارز & مليبيوز & ريبوز & ملى زبتوز & مانوز & مالتوز & آرابينوز & جدايه \\
\hline$+1-$ & - & - & + & - & - & + & + & PA1 \\
\hline$-1+$ & + & + & - & + & + & + & - & PA3 \\
\hline$+1-$ & + & + & + & - & - & + & + & PA6 \\
\hline$-/+$ & + & + & + & + & + & + & + & PA10 \\
\hline$+1-$ & + & + & + & - & - & + & + & PA12 \\
\hline$+1-$ & + & - & + & + & - & + & - & PA13 \\
\hline
\end{tabular}




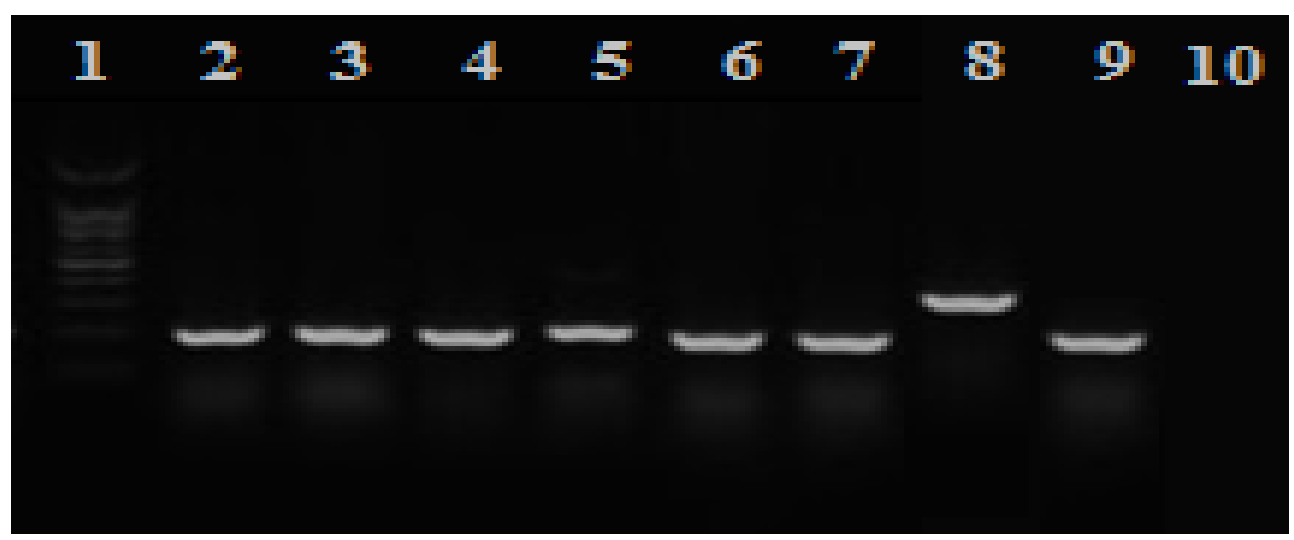

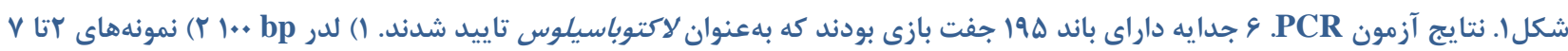

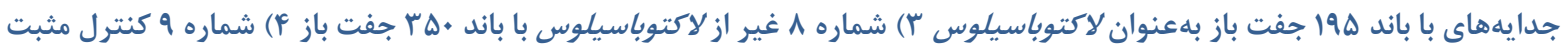

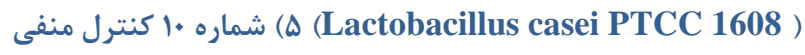

تحليل BLAST توالى بهدستآمده شباهت جدايه PA6 با لاكتوباسيلوس برويس را نشان داد كه نشان بر تاييد نتايج

$$
\text { بيوشيميايى و تشخيص صحيح گونه بود (شكل ب). }
$$

\section{توالى يابى} ارسال محصول PCR جدايه PA6 براى توالىيابى به شركت

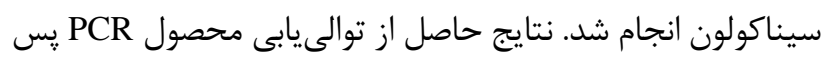

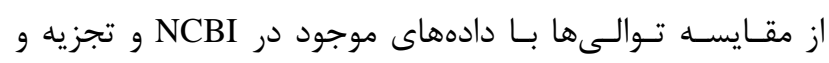

MT464328.1 Lactobacillus brevis strain 8466 KP793167.1 Lactobacillus brevis strain Lb2H - AB680070.1 Lactobacillus brevis strain NBRC 3345 - JN368471.1 Lactobacillus brevis strain ABRIIINW-K EU147303.1 Lactobacillus brevis strain BFE 8285 - MT544691.1 Lactobacillus brevis strain 4116 MT544691.1 Lactobacillus brevis strain 4116
JN792496.1 Lactobacillus brevis strain PB117 Mb MW221346.1 Lactobacillus brevis strain 12376 - MT611909.1 Lactobacillus brevis strain 2976 KP793173.1 Lactobacillus brevis strain Lb13H MT464157.1 Lactobacillus brevis strain 7872 LC582839. 1 Lactobacillus brevis LSF9-6 KX010095.1 Lactobacillus brevis strain F2a KJ.J095648.1 Lactobacillus brevis strain SD3S6L4 MF191696.1 Lactobacillus brevis strain VP-2.2 —MW295627.1 Lactobacillus brevis strain LBB KM495905.1 Lactobacillus brevis strain gp33 —MB66716.1 Levilactobacillus brevis strain 19222 KM495920.1 Lactobacillus brevis strain gp71 KJ095647.1 Lactobacillus brevis strain SD2S7L1 MW295577.1 Lactobacillus brevis strain ID16.2b - HM104306. 1 Lactobacillus brevis strain 0945
ونكومايسين و جنتامايسين مقاوم بود، همجنين اين سويه در برابر

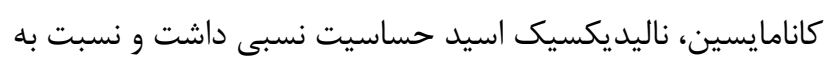

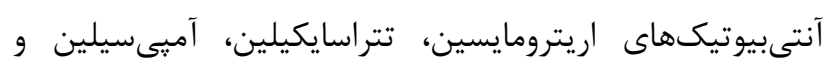
كلرامفنيكل حساس بود.

\section{مقاومت به آنتىبيوتيك}

نتايج مربوط به تست مقاومت به آنتىبيوتيك در جدول

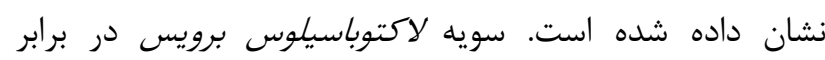


جدول rا. مقاومت جدايه لاكتوباسيلوس برويس در برابر برخى از آنتىبيوتيكهاى رايج

\begin{tabular}{|c|c|c|c|c|c|c|c|c|}
\hline ونكومايسين & كلر امفنيكل & آمبى سيلين & جنتامايسين & ناليد يكسيك اسيد & تتر اسايكلين & كانامايسين & اريترومايسين & سويه \\
\hline مقاوم & حساس & حساس & مقاوم & حساسيت & حساس & حساسيت نسبى & حساس & لاكتوباسيلوس برويس \\
\hline
\end{tabular}

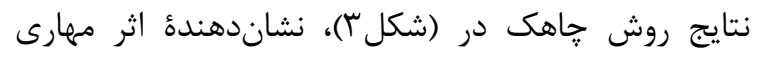

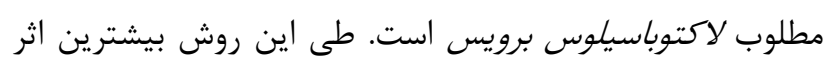

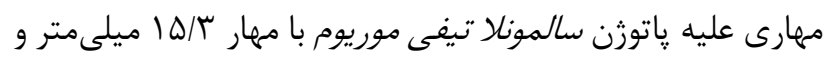

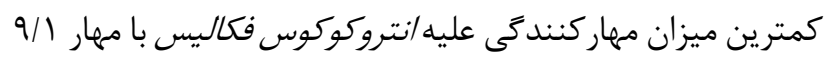
ميلى متر بود.

نتايج بهدست آمده در روش ديسك در (شكل ؟ ا)، نشاندهندة

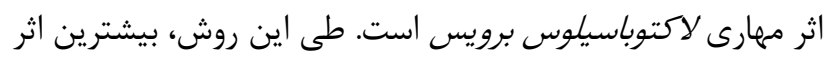

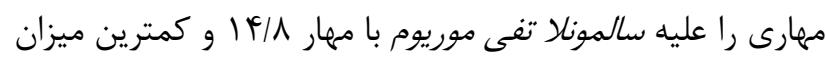

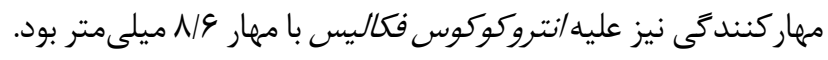

\section{بررسى فعاليت ضد ميكروبى}

فعاليت ضد ميكروبى مايع رويى كشت لاكتوباسيلوس بروبى برويس

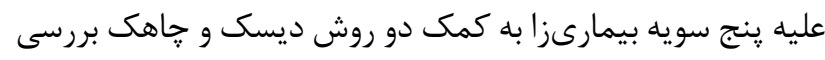

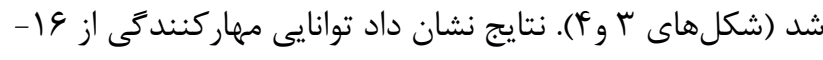

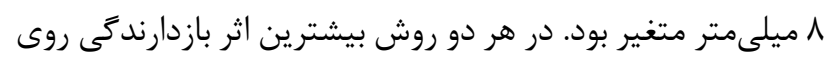

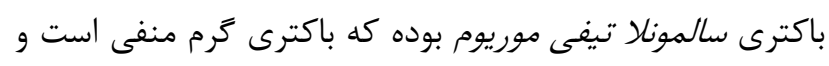

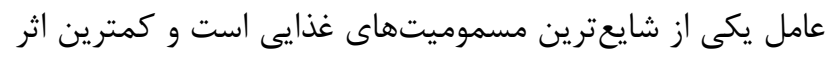

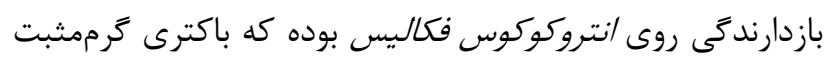

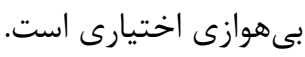

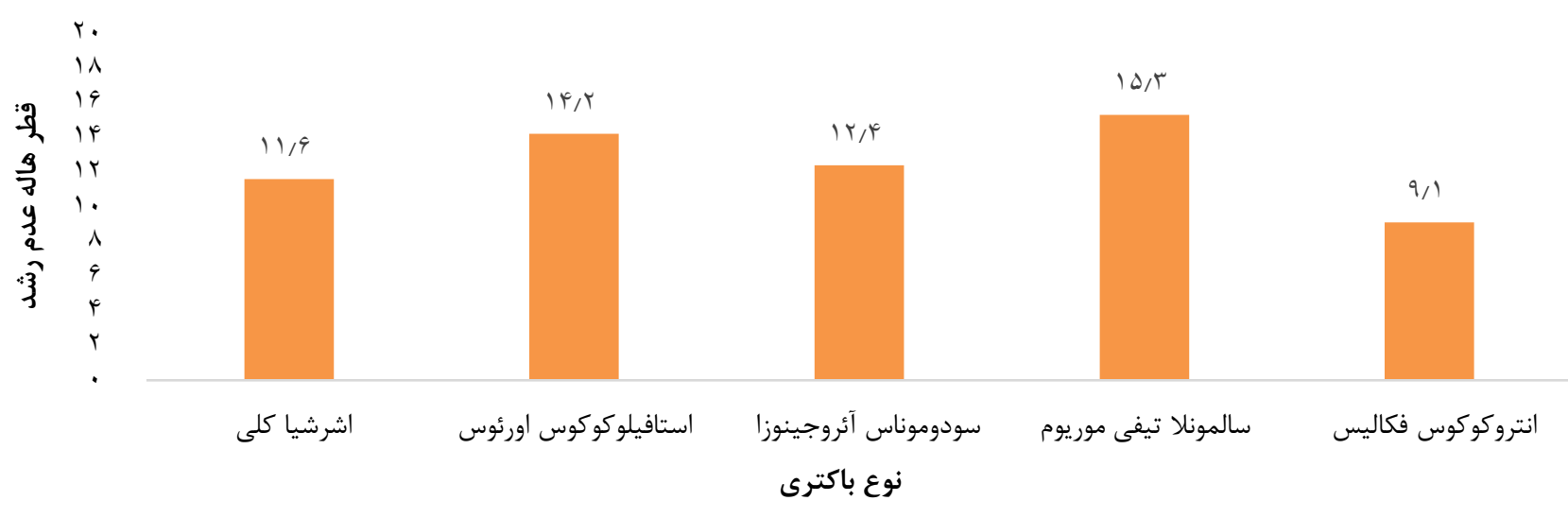

شكل r. قطر هاله عدم رشد در برابر باكترىهاى گاتوزن به روش حاهك

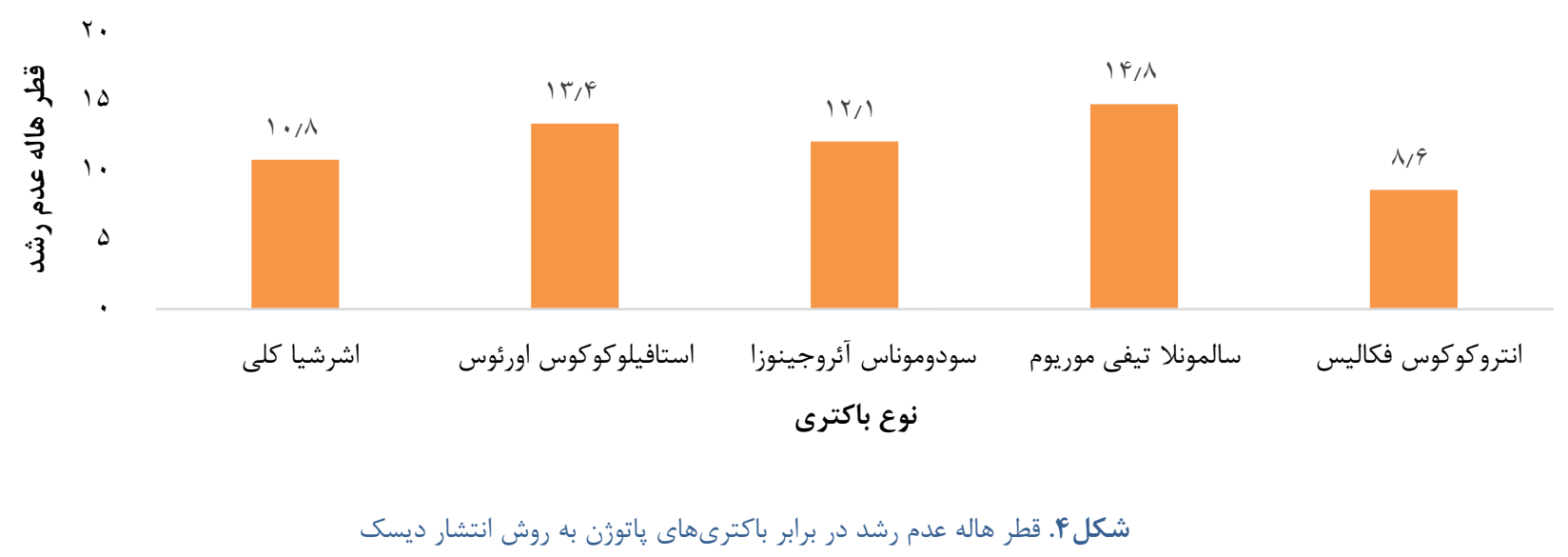


كونـــه لاكتوباسيلوس برويس و يك كونه لاكتوباسيلوس كازئى بود

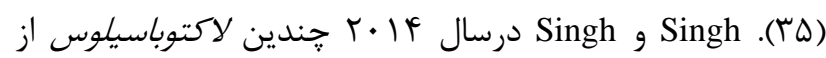

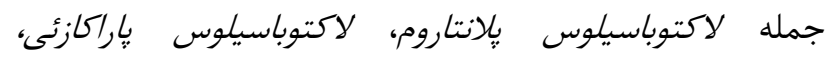

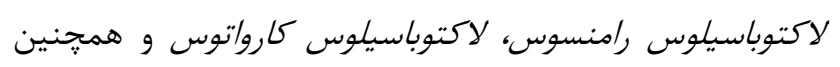

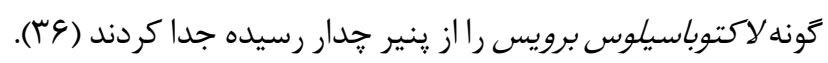
Abdali

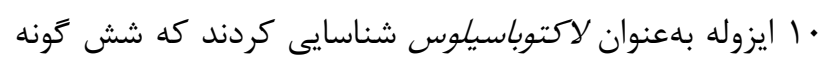

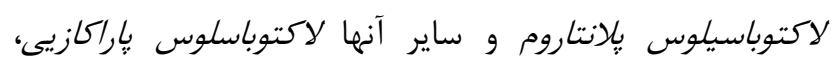

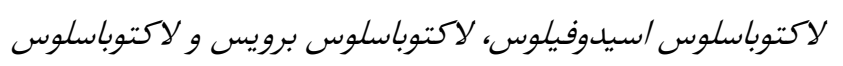

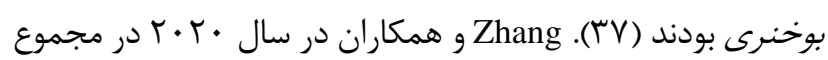

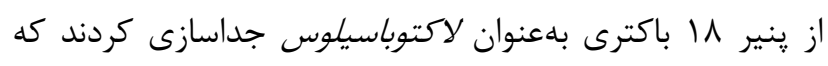

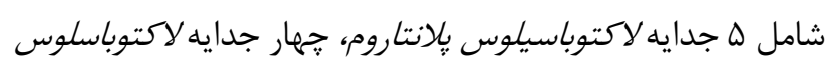

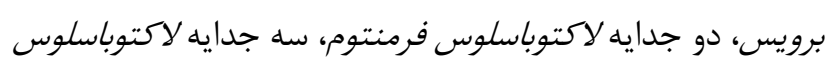

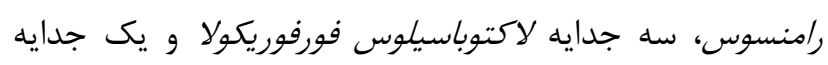
لاكتوباسيلوس بارا كازئى بود (^^).

بخش دوم اين يزوهش در مورد خاصيت ضدميكروبى

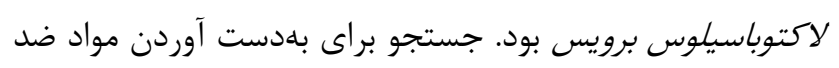

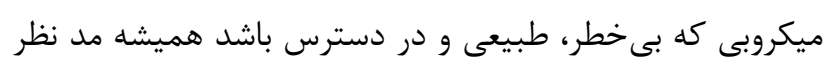

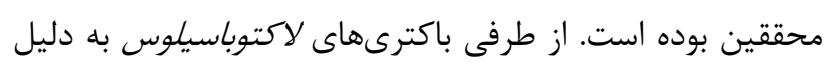

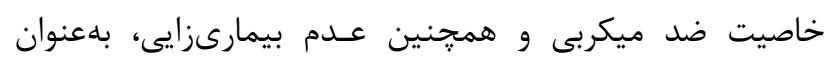

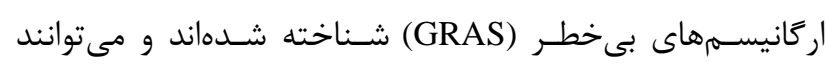

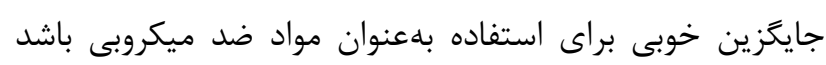

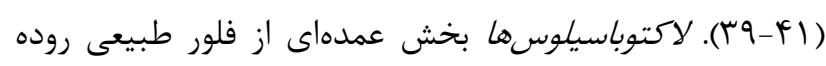

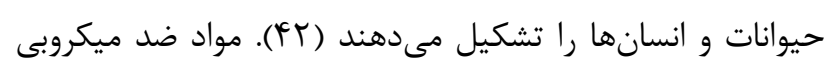

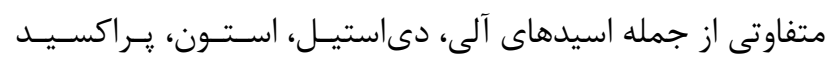

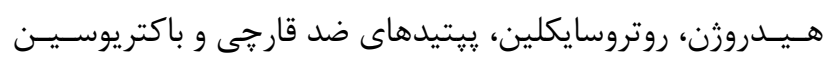

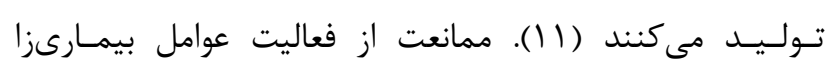

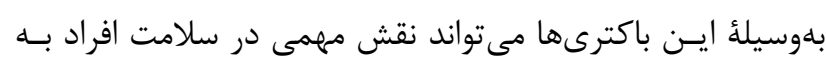

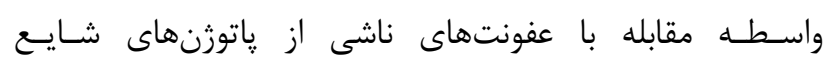

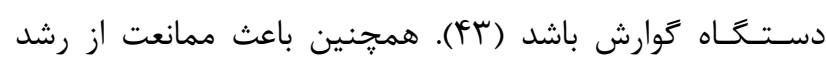

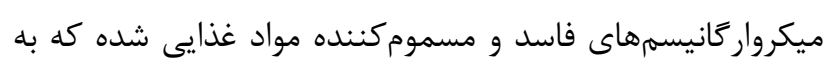

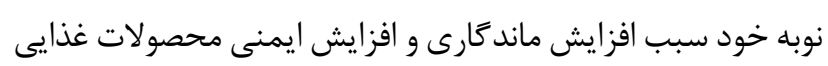

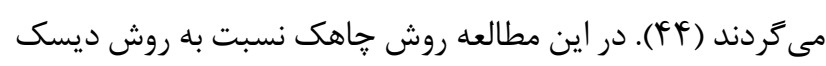

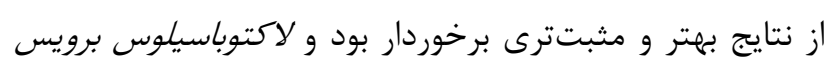

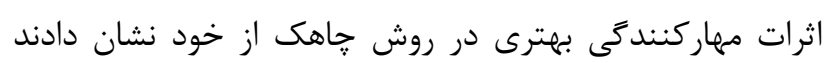

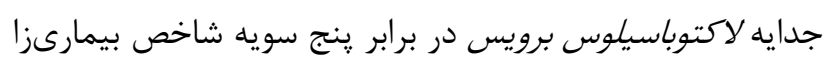

تنوع لاكتوباسيلوسها در محصولات غذايى و در شرايط

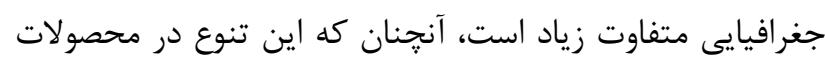

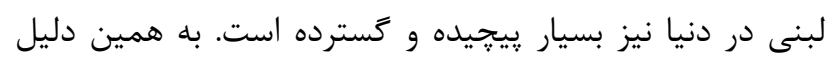

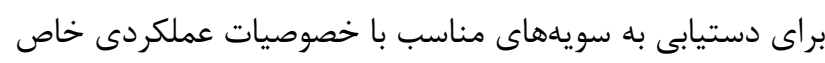

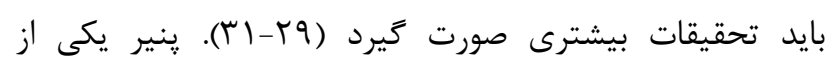

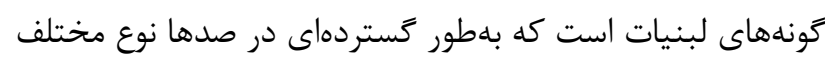

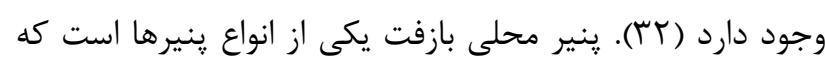

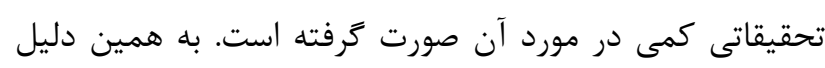

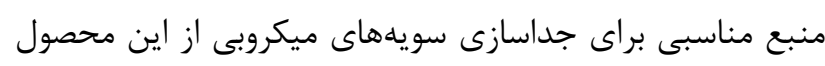

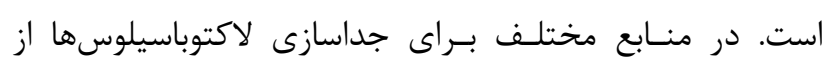

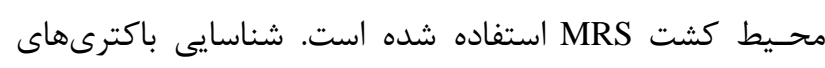

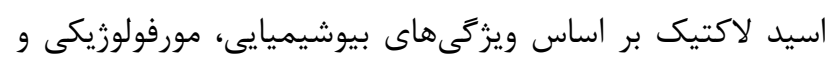

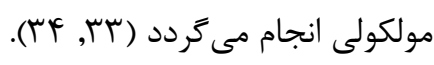

بخش اول اين يزوهش در مورد شناسايى مورفولوزيكى و

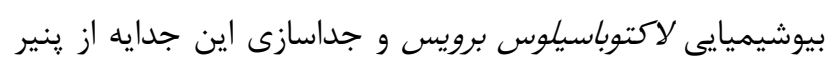

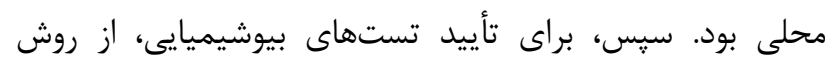

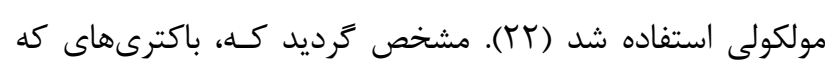
ميلهاى شكل با آرايش سلولى متنوع، گرم مثبت، كاتالاز منفى و و

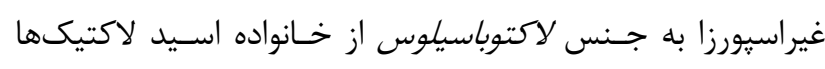

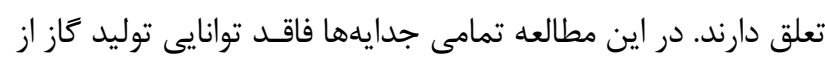

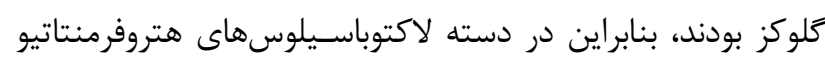

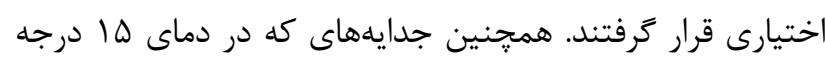

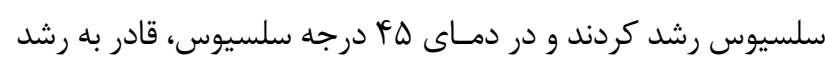

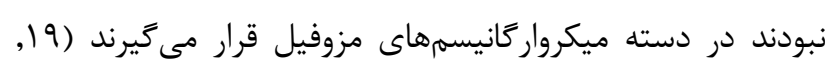

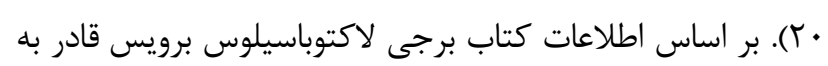

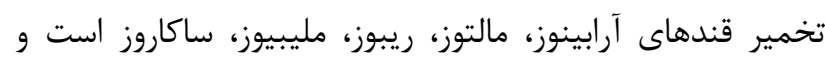

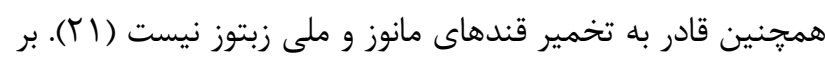

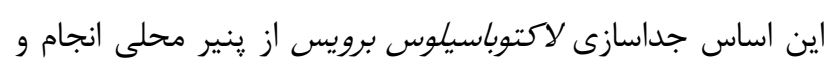

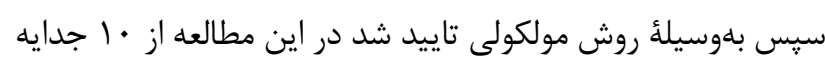

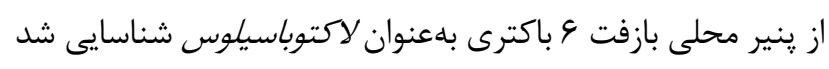

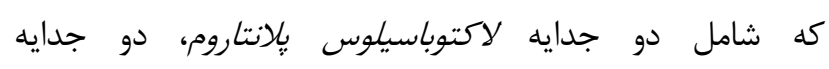

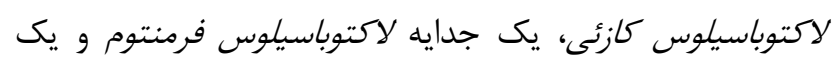

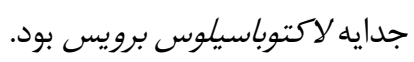

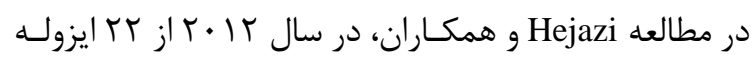

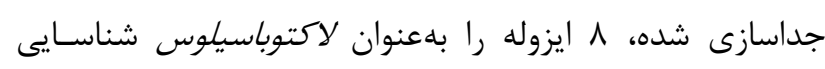

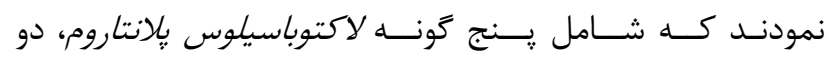


ونكومايسين مقاوم بود (^^^). در مطالعهُ Shazali و همكاران در سال

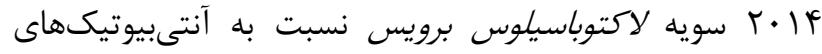
سييروفلوكساسين، تتراسايكلين و ونكومايسين مقاوم بود (49).

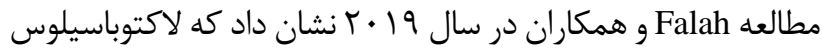
برويس به ونكومايسين و جنتامايسين مقاوم است و نسبت بهانهان

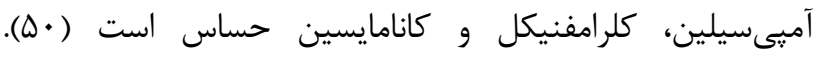
Khanmohammadi Otaghsara كردند سويه لاكتوباسيلوس برويس به آنتىبيوتيك ونكومايسين مقاوم است و نسبت به آنتىبيوتيكهاى تتراسايكلين و استر يتومايسين نيمه لئه

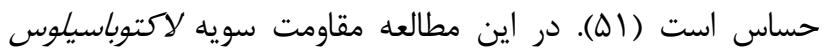

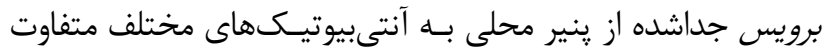

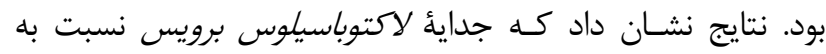

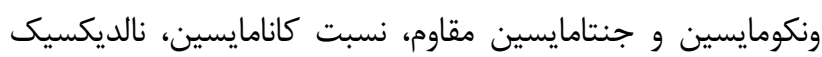
اسيد به حساسيت نسبى و نسبت به اريترومايسين، تتراسايكيلين، آمبىسيلين و كلرامفنيكل، حساس بود.

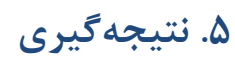

جداسازى ميكروار كانيسمها از منابع محلى، روشى مؤثر براى

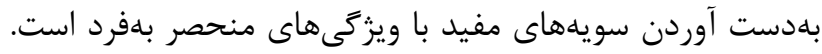

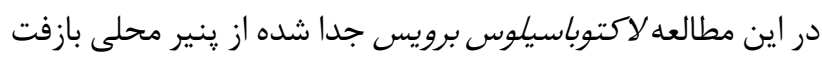

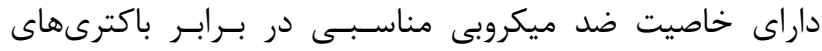

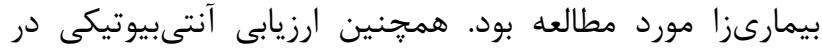

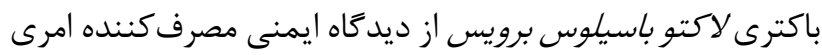

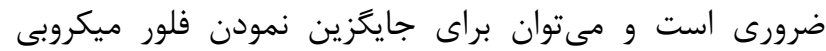
ازدسترفته دستخاه كوارش طى درمانهاى براى آنتى بيوتيكى بسيار

$$
\text { مورد توجه قرار كيرد. }
$$

بدين وسيله مراتب قدردانى و تشكر خود را از تمام كسانى كه در طول انجام اين يزوهش ما را يارى كردند اعلام مى وداريمه.

$$
\text { تعارض در منافع }
$$

بين نويسندكان مقاله تعارضى وجود ندارد.

$$
\text { منابع مالى }
$$

اين مقاله بدون حمايت مالى سازمانى انجام شده است.
عملكرد بالايى را از خود نشان داد مايع رويى كشت لاكتوباسيلوس

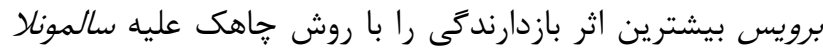

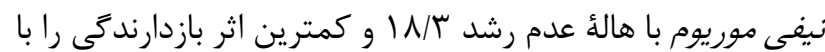

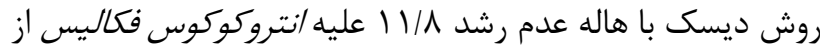

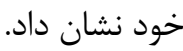

در مطالعه Azizi و همكاران در سال IV · F تأثير تركيبات ضد ميكروبى توليد شده توسط جدايه لاكتوباسيلوس برويس در برابر سه باكترى شاخص /ستافيلوكوكوس /ورئوس (ATCC 25923)، ليستريا

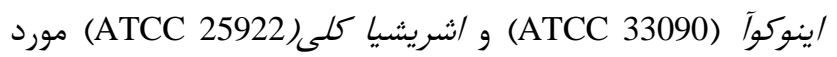
سنجش قرار كرفت. حساسترين باكترى/ستافيلوكوكوس /ورئوس و

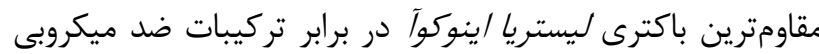

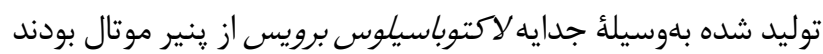

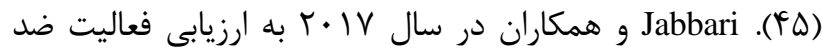
ميكروبى لاكتوباسيلوس برويس جداشده از ينير كوزه در برابر

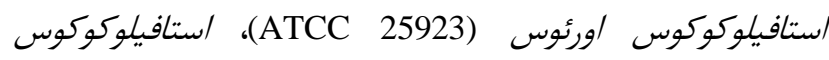
إيبرميديس (ATCC 12228)، سالمونلا تيفىموريوم ATCC

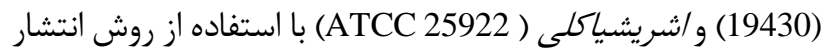
جاهك يرداختند. نتايج مطالعه آنها نشان داد بزركترين و كو جكترين

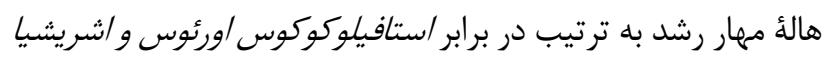

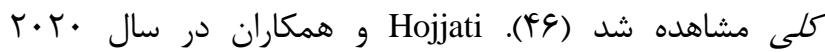
فعاليتهاى آنتاكونيستى و خواص ايمنى لاكتوباسيلوس برويس

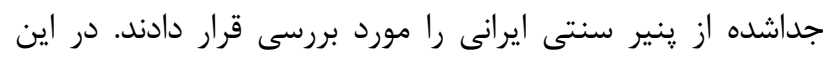

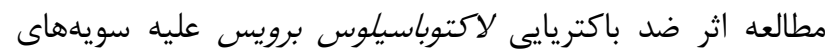

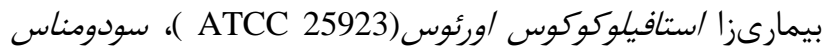
ائروجنوزا (PTCC 1707)، سالمونلا تيفى موريوم (PTCC 1609) و

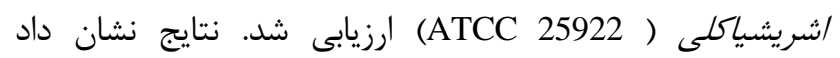
حساسترين گونه /ستافيلوكوكوس /ورئوس و مقاومترين كونه سالمونلا تيفى موريوم است (FV) (FV).

بخش سوم اين يزوهش در مورد حساسيت لاكتوباسيلوس برويس عليه آنتىبيوتيكهاى رايج بود. مكانيسم اثر آنتىبيوتيك بر بر برد

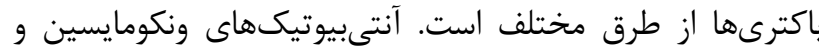

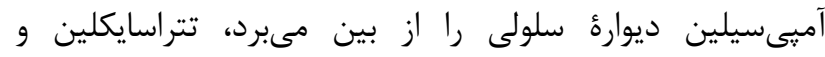

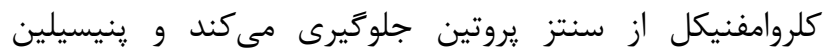
Kirtzalidou نفوذيذيرى سلول را تحت تاثير قرار مىدهد. در گزارشين

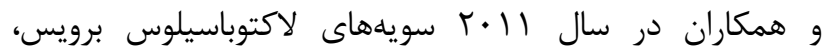

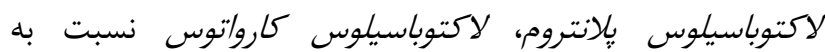

